\title{
Hydrogeology and hydrogeochemical modeling in phreatic aquifer of NE Mendoza, Argentina
}

\author{
M.L. Gomez ${ }^{1}$, J.N. Aranibarr, ${ }^{2,3}$ R. Wuilloud ${ }^{3,4}$, C. Rubio $^{1}$, D. Martinez ${ }^{5}$, D. Soria ${ }^{1}$, R. \\ Monasterio $^{6}$, P. Villagra², S. Goirán ${ }^{2}$ \\ ${ }^{1}$ Instituto Argentino de Investigaciones de Zonas Áridas (IADIZA). CCT-CONICET-Mendoza, Argentina \\ ${ }^{2}$ Instituto Argentino de Nivología, Glaciología y Ciencias Ambientales (IANIGLA). CCT-CONICET-Mendoza, Argentina \\ ${ }^{3}$ Facultad de Ciencias Exactas y Naturales, Universidad Nacional de Cuyo, Mendoza, Argentina \\ ${ }^{4}$ Laboratory of Analytical Chemistry for Research and Development (QUIANID-CONICET), Mendoza, Argentina. \\ ${ }^{5}$ Instituto de Geología de Costas y del Cuaternario. CONICET. Universidad Nacional de Mar del Plata. Buenos Aires, Argentina \\ ${ }^{6}$ Instituto de Biología Agrícola de Mendoza (IBAM-CONICET) Facultad de Ciencias Agrarias, Universidad Nacional de Cuyo. \\ Mendoza, Argentina
}

e-mail addresses: e-mail: lgomez@mendoza-conicet.gob.ar(MLG, correspondingauthor),jaranibar@mendoza-conicet.gob.ar(JNA),rwuilloud@mendozaconicet.gob.ar(RW),crubio@mendoza-conicet.gob.ar(CR),demarti@mdp.edu.ar(DM),ndsoria@lab.cricyt.edu.ar(DS),rmonasterio@mendoza-conicet.gob.ar (RM),villagra@mendoza-conicet.gov.ar(PV),sgoiran@mendoza-conicet.gov.ar (SG)

Received: 1 November 2013 / Accepted: 24 August 2014 / Available online: 30 October 2014

\begin{abstract}
The objectives of this study are to develop a conceptual hydrogeological model and evaluate groundwater hydrochemical characteristics of the aquifer in the Guanacache Travesía, in the central Monte desert of Mendoza (Argentina). The region has been granted to aboriginal communities for communal use and is experiencing economic development. The area has limited surface water resources and relies on groundwater for economic activities, and in many cases, for human consumption. There are no hydrogeochemical studies on the quality of this water as drinking water or its suitability for agriculture and raising livestock. The present study provides information on water quality and availability in the northeast of Mendoza Province. It includes a detailed review of relevant bibliography, including scattered and unpublished studies with geological and geomorphological data. It also includes water level measurements, a definition of water flow direction and hydrochemical analyses, including some trace elements and isotopic data. The hydrogeological model shows a discharge area characterized by vertical upward flows, evident by thermal waters, lakes, salt deposits and the presence of reduced arsenic in some boreholes. The dominance of fine sediments, low relief, scarce local precipitation, low recharge from precipitation, and low groundwater velocities result in long residence times for groundwater and poor renovation (with remote recharge area). Groundwater has high salt content and hardness, as well as trace elements such as fluoride and arsenic. Localized patches of low salinity waters are found along paleochannels. The isotopic signature of these waters indicates distant precipitation from the mountains, which could also have recharged the aquifer in historic times. In addition to the important geologic controls on surface and groundwater flows, human activities affect local conditions of the aquifer near livestock gathering areas, increasing nitrate concentrations and the proportion of As(III) relative to As(V).
\end{abstract}

Keywords: arid zone, phreatic aquifer, Telteca reserve, arsenic, isotopes, conceptual model

Resumen

El objetivo de este estudio es desarrollar un modelo hidrogeológico y evaluar las características hidroquímicas de las aguas subterráneas del acuífero de la Travesía Guanacache, en la zona central del desierto del Monte de Mendoza (Argentina). La región se ha cedido a las comunidades aborígenes para uso comunal y está experimentando un desarrollo económico. La zona cuenta con limitados recursos de agua superficial y depende de las aguas subterráneas para sus actividades económicas, y en muchos casos, para el consumo humano. No hay estudios hidrogeoquímicos sobre la calidad del agua para consumo humano, agrícola y ganadero. El presente estudio proporciona información sobre la calidad y disponibilidad del agua en el noreste de la provincia de Mendoza. Se incluye una revisión detallada de la bibliografía existente, incluyendo estudios geológicos y geomorfológicos dispersos y no publicados. En el presente estudio se recolectaron medidas de nivel estático, se definió la dirección del flujo de agua y se realizaron análisis hidroquímicos, incluyendo algunos elementos traza y estudios isotópicos. El modelo hidrogeológico evidencia una zona de descarga que se caracteriza por flujos verticales ascendentes, las aguas termales, lagunas, depósitos de sal y la presencia de especie reducida del arsénico en algunos pozos. El predominio de sedimentos finos, bajo relieve, la precipitación local escasa, baja recarga de las precipitaciones y bajas velocidades de agua subterránea como resultado largos tiempos de permanencia de las aguas subterráneas y baja renovación (con área de recarga alejada). El agua subterránea tiene alto 
contenido de sal y dureza, así como algunos elementos trazas, tales como fluoruro y arsénico. Algunas muestras de agua de baja salinidad se encuentran a lo largo de paleocanales. La firma isotópica de estas aguas indica precipitación distante en las áreas de montaña. Además del control que ejercen los procesos geológicos en y sobre los flujos de aguas subterráneas, las actividades humanas afectan a las condiciones locales del acuífero cerca de las zonas de corrales de ganado, pudiendo aumentar las concentraciones de nitratos y la proporción de As(III) con respecto a $\mathrm{As}(\mathrm{V})$.

Palabras clave: zona árida, acuífero freático, Reserva Telteca, arsénico, isótopos, modelo conceptual

\section{Introduction}

Semiarid and arid regions (i.e. drylands with mean annual rainfall between 25 and $500 \mathrm{~mm}$ ) cover approximately onethird of the world's land area and are inhabited by almost 400 million people (Williams, 1999). Water resources are limited in these drylands, so knowledge of groundwater dynamics, quality, and accessibility is crucial to human development. Arid areas are associated with highly saline waters due to evaporite minerals, salt precipitation and high evapotranspiration (Edmunds, 2012), which restricts groundwater for domestic livestock use, human consumption, and food production.

Extensive wetlands along river beds in the central Monte desert area of Mendoza Province, Argentina, sustained indigenous Huarpe communities in pre-Hispanic times, but this surface water has now been reduced to temporary ponds, which are not reliable for any permanent economic activity. Surface water from rivers is almost entirely diverted upstream for irrigation in near urban areas in agricultural oases, so groundwater is now the most important water source for local inhabitants. Rural communities use woodland with phreatophyte vegetation and groundwater resources for their primary economic activity, livestock production. Livestock settlements, generally made of up a family unit and their livestock, are sparsely distributed in the region, and use groundwater as the exclusive water source for animal and, in many cases, human consumption. Recent political changes have increased economic resources in the area, by providing electricity, fresh water for human consumption in some areas, and communal land rights for aboriginal communities. These changes may encourage settlement in the area, so an assessment of water resource availability, suitability, and vulnerability to different land uses is crucial for achieving sustainable activities in the region.

Groundwater is characterized by high saline and arsenic contents, which makes it generally unsuitable for irrigation of common crops and human consumption. However, groundwater with lower salinity is found in paleochannels and in areas with scarce vegetation, which may allow a local recharge (Jobbagy et al., 2011; Aranibar et al., 2011). Settlement densities are higher in paleochannels and alluvial plains, probably because of better quality and availability of groundwater (Goirán et al., 2012). The hydrological model proposed here aims to improve the understanding of chemical features of the aquifer's groundwater in non-irrigated lands of northeastern Mendoza.

\section{Study site}

The study area, 22,000 $\mathrm{Km}^{2}$ (Fig. 1), is in northeast Mendoza Province. It has a mean annual precipitation of $214 \mathrm{~mm}$ and a high potential evapotranspiration of $715 \mathrm{~mm} / \mathrm{y}$ (19572011, San Martín Series of National Weather Service data). These features generate a water deficit that results in an almost total consumption of precipitation by plants and negligible local recharge rates $(<1 \mathrm{~mm} / \mathrm{y})$ (Jobbágy et al., 2011).

The landscape is influenced by tectonic processes, which include active faults associated with the uplift of the Andes, and is characterized by dunes stabilized by vegetation. The sediments that cover the area include sand, silt, and very fine sands derived from aeolian processes, fluvial and lacustrine deposits of four nearby rivers, and saline playa lake deposits. Salts, such as $\mathrm{Na}_{2} \mathrm{SO}_{4}, \mathrm{NaCl}, \mathrm{CaSO}_{4}$, and $\mathrm{CaCO}_{3}$ have accumulated, generating deposits of economic interest that were exploited in the past (Sepúlveda, 2001; Carpio, 1999) (Fig. 1).

\section{Geomorphological Aspects}

In this paper, we used studies by Rodriguez (1966), Abraham (2000) and Martínez et al. (2008) to generate to generate a 1:250,000 scale geomorphological map (Fig. 1). This paper included geological structures, redefined the boundaries of geomorphological units, and regrouped different units to infer hydrogeological patterns. Geomorphological patterns are important in hydrogeological studies, especially in arid zones (Toth, 1999). Studies by Alvarez et al. (2009), in other arid areas of Argentina (outside the Patagonian Andes), indicate a correspondence between hydrogeological and geomorphological units. Stratigraphic and geophysical studies by Zambrano (1985), Sepúlveda (2001) and Martínez et al. (2008), helped us to define the structural framework. In addition, unpublished hydrogeological studies of irrigated areas by INA-CRA (Water National Institute, Andean Regional Center) were used to complete geological and hydrogeological descriptions.

\section{Materials and Methods}

\subsection{Hydrogeology}

A water table map was produced with elevation data and groundwater depths for 138 wells in the unconfined aquifer with well depth between 5 to $120 \mathrm{~m}$, data obtained during April 2010 and previous sampling trips in 2009. At each well, water 


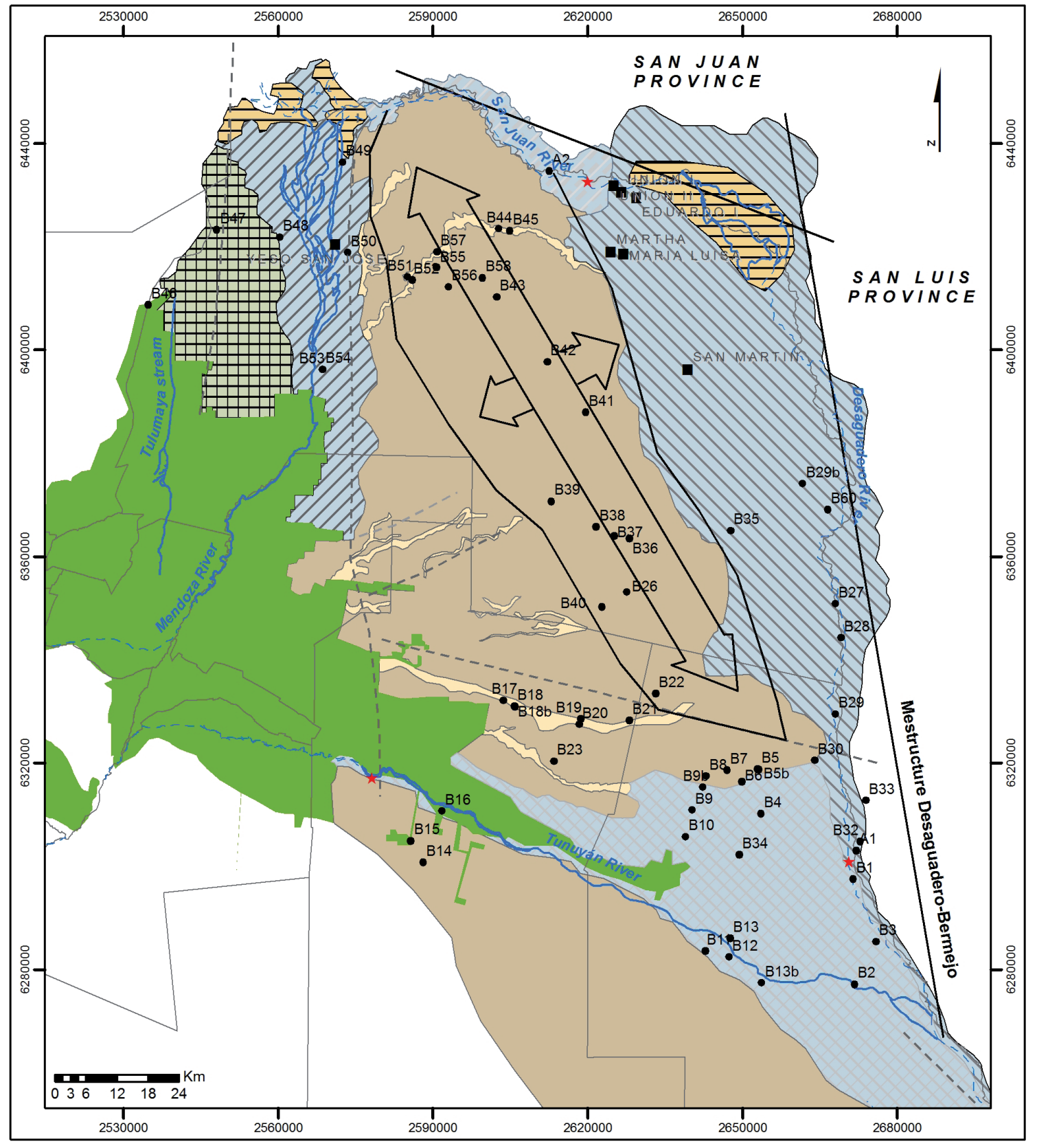

GEOMORPHOLOGICAL UNITS IN NORTHEAST MENDOZA

\section{Legend}

- Boreholes

$\star$ Surface samples

- Gypsium and sodium sulfate deposits

- - - Temporary river

_ Permanent river

- Infered fault

Fault

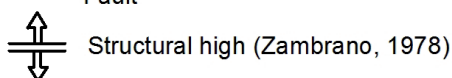
Political boundaries
Geomorphological units

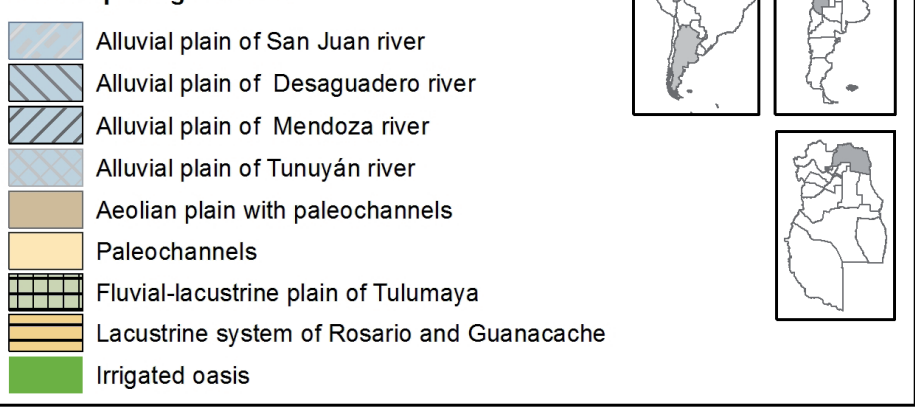

Fig.1.- The study area, showing different geomorphologic units, structures including gypsum and sodium sulfate deposits by Sepúlveda (2001). 
table depth was measured, and owner's information about filter depths, age of the borehole, soil texture (presence of calcrete/ clay levels during well construction) were recorded. Hydraulic heads (h) were calculated based on water-table depth (w) and elevation data obtained from the SRTM-DEM. (Shuttle Radar Topography Mission- Digital Elevation Model).

Aquifer's boundaries and hydraulic parameters were estimated based on on texture analyses, hydraulic tests from studies by Groundwater Regional Center (CRAS,1978), in a multilayer aquifer in the irrigated area (Lavalle, Desaguadero, and La Paz; CRAS, 1978) and geological studies by Rodriguez (1966).

Seventeen sediment samples (aeolian and alluvial sediments), from the surface to $3.5 \mathrm{~m}$ depth, were collected for textural and mineralogical analyses. Grain size was measured with sieves for the sand fraction by standard ASTM (1993). Particle sizes were used to estimate porosity and permeability of the sediments in the saturated and unsaturated zones, because these parameters are largely derived from, or strongly dependent on this primary textural property (Last and Smol, 2002). This is a relevant approximation in an area where it is not feasible to do pumping tests. Integrating the information, hydraulic conductivity $(\mathrm{K})$ and effective porosity $(\mathrm{Pe})$ were estimated from the literature for similar materials (Struckmeier and Margat, 1995; Domenico and Schwartz, 1990; Custodio and Llamas, 1983).

\subsection{Hydrochemistry}

For surface water characterizations, 4 samples were taken, one from each river in the same day. Forty two wells were selected for groundwater sampling, resulting in an approximate sampling density of 1 well per $500 \mathrm{Km}^{2}$. Groundwater samples from the unconfined aquifer (during autumn season with $19^{\circ} \mathrm{C}$ of average temperature) were collected from rural wells, including windmills and domestic wells with electric pumps. Sampling depth ranged from 4 to $320 \mathrm{~m}$. This study excludes bucket wells, hand-drilled wells in which water is manually drawn with buckets. Bucket wells, of $1 \mathrm{~m}$ diameter, were only used to obtain water-table level data, as they do not reflect natural groundwater conditions, due to over 60 years of evapotranspiration and their sanitary conditions.

Electrical conductivity (EC) and water temperature were measured in the field with portable equipment. Water samples were collected in polyethylene bottles, previously washed with distilled water and kept refrigerated until analysis. Samples for arsenic concentration were collected in bottles washed with $10 \%$ nitric acid, placed in a cooler in the field, and stored below $4^{\circ} \mathrm{C}$ until laboratory analysis. Major ions $\mathrm{HCO}_{3}^{-}, \mathrm{CO}_{3}^{-2} \mathrm{SO}_{4}^{-2}, \mathrm{Cl}^{-}, \mathrm{Na}^{+}, \mathrm{K}^{+}, \mathrm{Ca}^{+2}, \mathrm{Mg}^{+2}$, minor ions $\mathrm{NO}_{3}^{-}$ , $\mathrm{NO}_{2}^{-}, \mathrm{Si}$ and trace elements $\mathrm{F}^{-}$and $\mathrm{As}_{\text {(Total) }}$ were analyzed. Major ions were analyzed in LASAF Laboratories according to Standard methods of APHA -American Public Health Association-, AWWA -American Water Works Association-, WPCF -Water pollution Control Federation- (1995). Fluoride and silica contents were analyzed in IANIGLA laboratory using a spectrophotometer Hach DREL/2010. Arsenic speciation was analyzed with a high-performance liquid chromatography coupled to hydride generation atomic fluorescence spectrometry (HPLC-HG-AFS). A Hamilton PRP-X100 anion exchange column was used.

Natural abundance of stable isotopes $\left(\delta^{18} \mathrm{O}\right.$ and $\left.\delta^{2} \mathrm{H}\right)$ was analyzed in samples with salinities lower than $5000 \mathrm{mg} / \mathrm{l}$ in the Stable Isotope Hydrology Laboratory at the National University of Mar del Plata, with a Los Gatos Research DT-100 Liquid-Water Isotope Analyzer. Five samples with high salinity were analyzed in SIREAL (Stable Isotope Ratios in the Environment Analytical Laboratory), University of Rochester, USA. The values are referred to V-SMOW (Vienna Standard Mean Ocean Water; Gonfiantini, 1978). Previous studies by Panarello and Dapeña (1996) provided stable isotope data for dam water in the irrigated oasis area. Local Meteoric Water Line (LMWL; $\delta^{2} \mathrm{H}=8.35 * \delta^{18} \mathrm{O}+10.03$ ) was calculated using data from Aranibar et al. (2011), and Hoke et al. (2013).

In order to detect recent local recharge in the paleochannel of the Mendoza river and in the southern paleochannel (Fig. 1), tritium content was analyzed in samples from groundwater. Tritium abundances were determined at the INGEIS laboratory with TU analytical errors between $\pm 0.2 \%$ and $\pm 0.3 \%$.

Mineral saturation indices (SI), for each mineral phase was calculated with Netpath software (Plummer et al., 1991) based on the chemistry of analyzed samples. A conceptual groundwater flow model was used to select 17 pairs of initial and final samples along the same flow line, in order to run inverse and mixing models, and to define mass-transfer reactions (dissolution, precipitation, ion exchange, and mixing) between dissolved constituents and the aquifer material. The phases included in the model were selected based on mineralogical analyses by Cordini (1948) and Carpio (1993). In this study, very fine sand fractions of 11 surface samples distributed in the Aeolian plain and the Fluvial plains (floodplains) of the Mendoza and Desaguadero rivers were separated for mineralogical analyses done with a NIKON petrographic microscope. Five additional samples, 3 taken from the surface, one at $1.3 \mathrm{~m}$, and the fifth at $8 \mathrm{~m}$ depth, were analyzed in Universidad Nacional del Comahue, with X-ray diffraction (XRD) techniques.

\section{Results and Discussion}

\subsection{Geomorphology and structural characteristics}

Early studies in northeast Mendoza (Rodriguez, 1966) describe the area as the most homogeneous morphological unit in the province; it is unusual for being a filled in depression, that is lower than surrounding units. The plains are part of an extensive piedmont depression dating to $15 \mathrm{Ma}$, coinciding with the uplift of the Frontal Cordillera, that was then filled with about $5000 \mathrm{~m}$ of Cenozoic deposits (Sepúlveda, 2001). The sedimentary sequence is comprised of fluvial and aeolian 
sediments from higher surroundings areas (Sepúlveda, 2001; Rodriguez, 1963).

Figure 1 shows the geomorphological units in the area. The units Alluvial plain of the Desaguadero river, Alluvial plain of the Mendoza river and Fluvial-lacustrine plain of Tulumaya are characterized by salinization processes. The units Lacustrine system of Rosario and Guanacache and Alluvial plains of the San Juan river are wetlands, marshes and lagoons along river courses.

The Mendoza and Tunuyán Rivers have their head waters in the Andes and like the Tulumaya, are dry most of the year. They occasionally drain excess irrigation water and rainfall in the rainy season.

The unit Aeolian plain with paleochannels includes the greatest part of the study area, with a general uniform slope to the east and northeast $(0.47 \%$ on average). Locally, the central-northwest part of the unit presents a slightly sloping relief due to the presence of dunes. Outcropping materials are mainly aeolian, composed of very fine and fine sands, with dunes stabilized by vegetation, and reworked by winds. Testimony of the villagers and field observations suggest that the dunes are stable. This is supported by the presence of 100-year-old Prosopis trees (Alvarez et. al, 2011; Giantomasi et al., 2013), whose roots have not been exposed or covered by dunes. The presence of phreatophytic woodlands is a determining factor in fixing and stabilizing dunes.

Image analysis indicates that lakes in the northeast of the study area are associated with the paleochannels of the Desaguadero and San Juan rivers, the distal part of the Tulumaya stream, low areas and blowouts.

The topographic digital analysis, using Microdem 12.0 and SAGA software, suggests changes in slope gradient and direction. Seismological data from INPRES (2013) indicates active faulting, and suggests the presence of one or more faults at depth (Fig. 2). A blind fault at depth, with $\mathrm{N} 15^{\circ} \mathrm{W}$ trending was identified. Even though the lack of geophysical information makes it difficult to infer its configuration at depth, it believes that the fault may be rooted in a regional detachment horizon located at a depth of ca. $6 \mathrm{Km}$ in the Barrancas area (Chiaramonte et al., 2000). Chiaramonte et al. (2000) suggest that the structure of the Barrancas anticline becomes shallower to the east, indicating that the fault in the basement corresponds to a very shallow structure $(<6 \mathrm{Km}$ in depth) in northeast Mendoza. In an unpublished map, Zambrano (1978) marked an inferred north-south fault in the same area, as well as east-west faults. The proximity to the Andes leads us to presume a structural framework in which pre-Andean structures were reactivated during Andean orogeny. The inferred blind fault, with no significant surface expression, has its tip line at depth. The structural model suggests the existence of a triangular zone above this line, as presented in Figure 2, where the deformation is concentrated.

Based on geophysical information, Zambrano (1978) identified a structural high toward the east of the inferred fault. His studies show that the structure may be continuous at the depth of the rocks that make up the hills of Pie de Palo (1000
Ma), located in the north of the study area. The location of the eastern boundary, based on topographic features and field evidence was redefined. The boundary coincides with a series of chain lakes and livestock settlements with groundwater near the surface, at less than $0.2 \mathrm{~m}$ depth (Fig. 2). In this area, the Paleozoic basement is $3000 \mathrm{~m}$ below, Mesozoic and Cenozoic sedimentary rocks. Zambrano (1978) proposed that this structural high was responsible for migrations and locations of river channels in the area: the Mendoza river to the west, the Tunuyán river to the south, the Desaguadero river to the east and the San Juan river to the north (Bordonaro, 2012). This is supported by movements of the Mendoza and Tunuyán rivers recorded by Abraham and Prieto (1981) and Prieto and Chiavazza (2005), which can be seen in the positions of their successive paleochannels. The model suggests the existence of a deformation zone, concentrated in the area. This zone has been the epicenter of numerous recorded earthquakes (Fig. 2).

\subsection{Hydrogeological Setting}

Towards the center and east of the study area, the unconfined aquifer consists of $75 \mathrm{~m}$, in the west, to $250 \mathrm{~m}$, in the extreme east, of fine sands and silts of aeolian and distal fluvial origin (Fig. 2).The phreatic level, $4-15 \mathrm{~m}$ depth, and the base are defined by a clay layer according to the only stratigraphic information from 3 boreholes descriptions by CRAS (1978). Layers of gypsum and volcanic ash are interbedded or disseminated (Fig. 2) in detrital sediments of unsaturated zone and in the aquifer, as can be observed in boreholes and lithological descriptions.

The unconfined aquifer is used by rural communities for domestic animals, and in many cases is the only water supply. According to more than 15 boreholes descriptions by CRAS (1978) from the irrigated area, the unconfined aquifers may present multilayer characteristics in the west and south of the study area, near the Mendoza and Tunuyán rivers. In this area very fine upper tertiary and quaternary sediments are interbedded with coarse grain sediments associated with alluvial fan processes. In the alluvial plain of these rivers, levels of plastic clays of variable thickness (between 3 to $15 \mathrm{~m}$ ) are interbedded with fine or medium sand levels at some sites, between 5 and $25 \mathrm{~m}$ thick (Fig. 2). Alternating materials of different textures and a lack of lateral continuity result in a multilayered, heterogeneous, and anisotropic complex system, with a succession of semiconfined/confined aquifers that may or may not be connected.

The outcropping sediments in the study area are mainly aeolian and alluvial (floodplains and paleochannels). Textural analyses indicate a homogeneous texture, where fine and very fine sands are dominant. Fine sand is the predominant grain size (from 30 to $78 \%$ ), followed by very fine (from 27 to $50 \%$ ), medium, and coarse sands with a maximum of $46 \%$ in paleochanels, and clay and silt (less than 15\%) which are the least abundant grain sizes. 


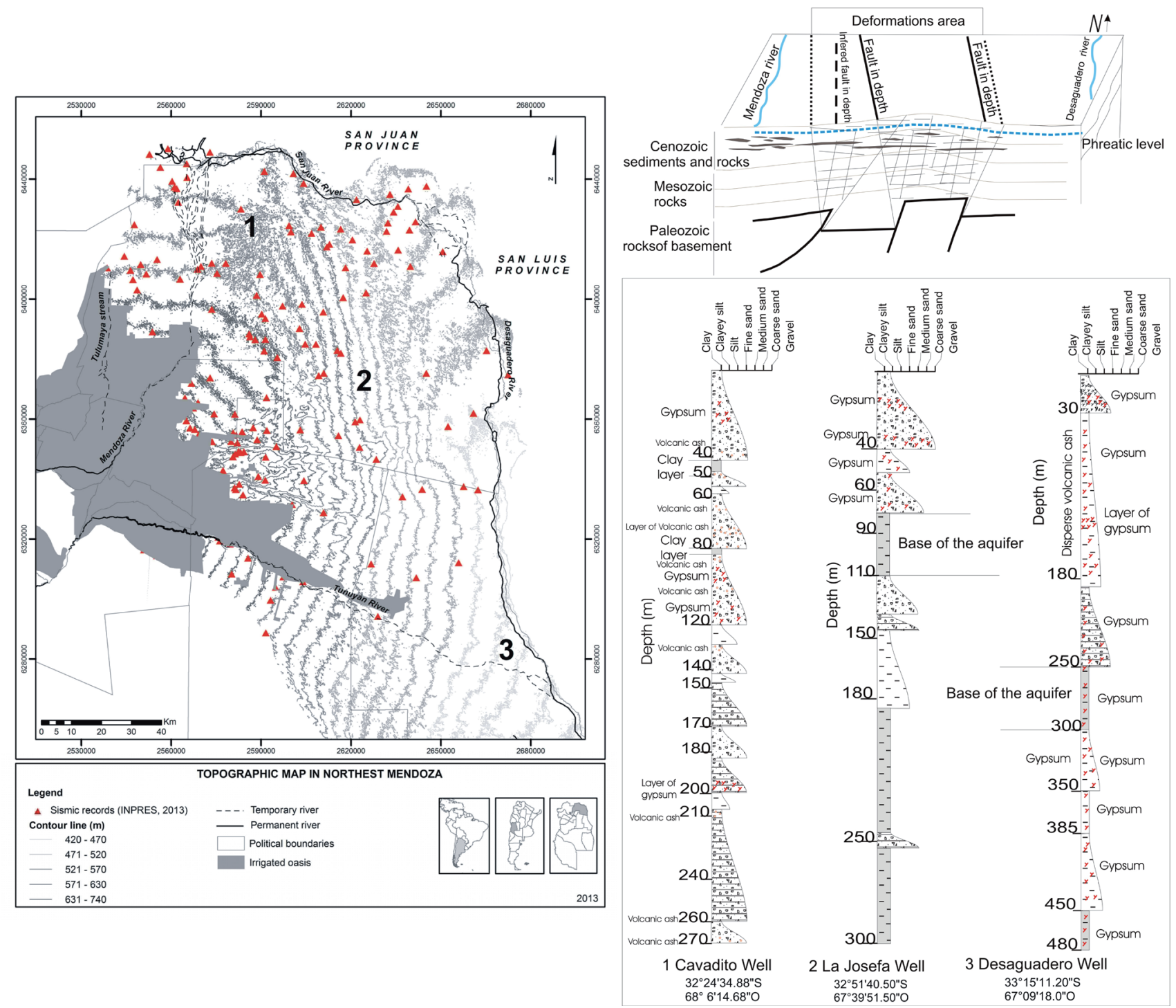

Fig. 2.- Topographic map with contour lines every $10 \mathrm{~m}$, and earthquakes recorded by INPRES (2013). The diagram on the right shows the area affected by the structures. Numbers 1, 2 and 3 indicate the location of representative boreholes and lithological descriptions by CRAS (1978).

Although the thickness of eolic sediments has not been studied in northeast Mendoza, Sepulveda (2001) notes that along the lower stretch of the river, eolic material may be 100 $\mathrm{m}$ thick. The tertiary-quaternary limit is not clearly defined and in this study both were considered as a hydrogeological single unit.

The general direction of groundwater flow in the aeolian unconfined aquifer is southwest to northeast (Fig. 3). The equipotential map shows groundwater discharges into the Desaguadero river, contributing to its base flow. The lower stretch of Mendoza, San Juan and Tunuyán rivers show influent relationships with the aquifer (Fig. 3). The radial flow from the oasis area is the same as flow directions defined by CRAS (1978) in the irrigated oasis (upgradient), which include the recharge area of the aquifer (Panarello y Dapeña, 1996; Jobbágy et al., 2011).

The thickness of the unsaturated zone varies between 4 and $15 \mathrm{~m}$, and is closer to the surface in wells located near the
Desaguadero and Tunuyán rivers. Residents report that there have not been large variations in water-table depth over the last 70 years, and field measurements of water-table depth at selected wells showed no changes for over two consecutive years.

The following values of hydraulic parameters for the upper part of the unconfined aquifer were estimated: Hydraulic Conductivity (K) $0.1-5 \mathrm{~m} /$ day, Transmissivity (T) 7.5-1250 $\mathrm{m}^{2} /$ day, coefficient Storage (S) or effective porosity 3-15\%; these values are consistent with an aquifer with good to poor yield. Deep, fine levels are interbedded with coarse sands, reflecting the sedimentary filling of alluvial fans in northeast Mendoza. Studies by CRAS (1978) in irrigated areas, indicate lower values of $\mathrm{K}$ than it was estimated. Hydraulic conductivity values may vary according to the scale of the study. As Lorant and Rudolph (1997) mention, the scale-dependence of $\mathrm{K}$ in low-permeability sediments has been extensively documented (Neuzil, 1986; Keller et al., 1989; Bradbury and Mul- 

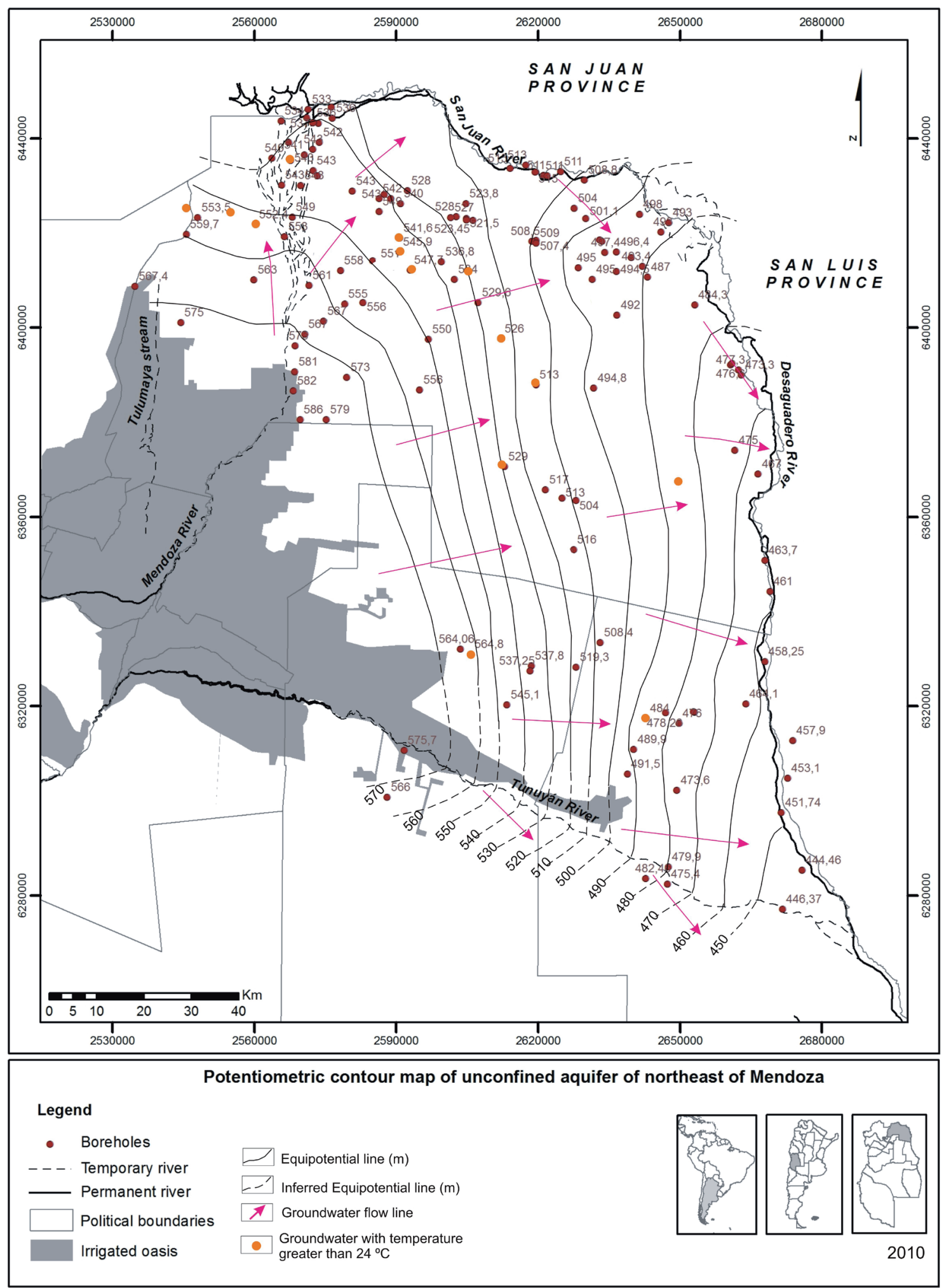

Fig. 3.- Equipotential map showing the groundwater flow directions, and the locations of thermal groundwater wells.

doon, 1990) and is often associated with spatial heterogeneity and macropore features.

Low groundwater velocities (between 0.1 and $0.25 \mathrm{~m} /$ day), calculated with the estimated hydraulic parameters and the equipotential map, are related to the flat relief of the area and the fine sediments generate low $\mathrm{K}$ and $\mathrm{S}$.
A particular characteristic of the study area is the occurrence of groundwater with abnormally high temperatures (different from the global geothermal gradient) (Fig. 4). Northeast Mendoza has extreme average temperatures (Abraham et al., 2008), so the average temperature of $17.5^{\circ} \mathrm{C}$ from a long data series (1900-2010) obtained from the NCEP 
Reanalysis Dataset (Kalnay et al., 1996) was used.. Mean water temperature of aquifer samples was $23.5^{\circ} \mathrm{C}$. According to Shoeller's classification (1962), these groundwaters would be in the group of thermal groundwaters which are more than $6^{\circ} \mathrm{C}$ above average annual temperature (Table 1 and Fig. 4). A good correlation between depth and water temperature $(\mathrm{R}=$ 0.78 ), with local gradients reaching $10^{\circ} \mathrm{C} / 90 \mathrm{~m}$ was observed. In some areas, unusually high geoundwater temperatures were found, e.g. $25.6^{\circ} \mathrm{C}$ at $7.5 \mathrm{~m}$. This groundwater temperature may be explained by the presence of an active fault in the central part of the study area, as mentioned above. Vertical upward flow of warmer groundwater may be responsible for such high temperatures at shallow depth. Low level of seismic activity and a very low local precipitation recharge do not cause evident horizontal changes in groundwater flow directions. Vertical upward groundwater flows probably allow deep, warmer groundwater to rise closer to the surface, as it will be shown later in the conceptual model.

\subsection{Hydrogeochemistry}

Groundwater in northeast Mendoza has a high salt content, with Total Dissolved Solids (TDS) between 570 and 26,300 $\mathrm{mg} / \mathrm{l} ; 70 \%$ of the samples are from brackish and salty water (Table 1). This percentage shows homogeneity in groundwater salinity, as well as low variability in samples from the same geomorphological unit and between different geomorphological units. Shallow groundwater are generally more saline, although the few available data from deep wells could limit this generalization. The highest salinity, $26,300 \mathrm{mg} / \mathrm{l}$, was found in the fluvial-lacustrine plain of Tulumaya (Fig. 1). This geomorphological environment is a structural graben, where the Mendoza river discharges and groundwater flows converge and evaporation becomes the dominant process. Lower salinity groundwater, with concentrations lower than $1500 \mathrm{mg} / \mathrm{l}$, were found in the paleochannel unit and at a few wells in the aeolian plain. These samples may derive from past local recharge of the Mendoza river, when the river flowed along this dry river bed. Historic documents and archeological remains suggest the historic presence of rivers in the paleochannel, and abrupt changes of river directions (Prieto and Abraham, 2000; Chiavazza and Prieto, 2008). Paleo-Archaeofaunal studies show reactivation of flow in the channel within a period between ca. 1600 and 200 years BP (Chiavazza, in press). Based on these different lines of evidence, the better quality (i.e., lower salinity) groundwaters found in the paleochannels may not be considered renewable, because the river has permanently changed its course.

The sample collected in Arroyito village (B60) at a depth of $7 \mathrm{~m}$, had the lowest salinity $(570 \mathrm{mg} / \mathrm{l})$. This well captures low volumes of rainwater during the rainy season, which are collected on the surface and artificially stored in soil ditches; surface water then infiltrates into the ground (B60) (Fig. 1). The chemical composition reveals mixing of groundwater and local precipitation (arid climate $<200$ $\mathrm{mm} / \mathrm{y}$ ) or fresh water form Mendoza rivers when it flowed in past times, but stable isotope analysis are necessary to confirm this hypothesis. Our hypothesis considers the rainwater penetrates up to $8 \mathrm{~m}$ into the soil, where a layer of very thin sands and silts with carbonate cementation creates a perched water table. Rainwater quickly removes minerals from the sediments in the unsaturated and saturated zones, increasing water salinity. A similar effect has been observed in groundwater from an unvegetated dune area, Altos Limpios (Jobággy et al., 2011), but it is considered as a restricted process with very local effect.

Groundwater was alkaline, with $\mathrm{pH}$ values between 7.1 and 9 (Table 1). Water chemistry of the unconfined aquifer is mostly sodium and calcium sulfate. Although the Piper diagram (Fig. 5) shows a general evolution from sulfate to chlorinated groundwater, this evolution is not reflected in the field, where groundwater does not show a clear chemical evolution in the flow direction. The presence of layers with more fine texture and salt compositions (gypsum and mirabilite salt deposits, Fig. 1 and Fig. 3) generate particular changes in chemical reactions that conditioned the chemical composition of water along the flow path, i. e. local and preferential ion exchange processes instead of salt dissolutions. However, analyzing the evolution along the local and short flow lines, an evolution from calcium/sulfate-chlorinate to sodium/sulfate-chlorinate is observed (Fig.6). This behavior is related to the homogeneous composition of the aquifer, where sulfate is the dominant anion, with predominance between $50 \%$ and $80 \%$. Calcium and sodium are the dominant cations with the same percentages (Fig. 3 and Fig. 6). The sample collected in Arroyito village (B60) was the only one of the calcium bicarbonate water type.

The Tunuyán and Mendoza rivers (the latter sampled upstream of the study area) have the lowest salinity (Table 1). The Desaguadero river is the saltiest with $7780 \mathrm{mg} / \mathrm{l}$, probably because of its larger catchment drainage area and the influence of groundwater. The Mendoza, Tunuyán and San Juan rivers are affluents of the Desaguadero river (Fig. 3). In the Piper diagram (Fig. 5), the Desaguadero is located as an end member of those rivers. Water compositions show an evolution from calcium sulfate to sodium chloride, from the Tunuyán, Mendoza and San Juan to Desaguadero rivers, with sodium chloride compositions typical of brine environments. It is assumed that surface water compositions do not change during the year, following studies by Crespo et al. (2012) in the upper basin of the Mendoza River, where it was observed that most surface water chemical compositions remained unchanged over one year of sampling.

\subsection{Nitrate and trace elements}

Nitrate concentrations in groundwater vary over space and depth (Table 1), with low values (on average $8 \mathrm{mg} / \mathrm{l}$ ). Lower concentrations of nitrate $(0.4$ and $1.6 \mathrm{mg} / \mathrm{l})$ were found in wells located in a dry river bed and deep wells. Nitrate 


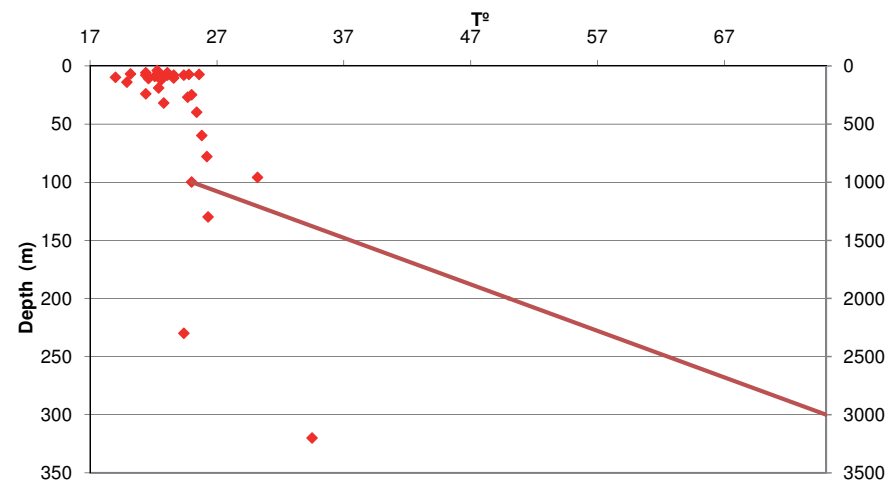

Fig. 4.- Groundwater temperature vs. depth (points). The line shows the geothermal gradient in the Earth crust.

concentrations up to $9 \mathrm{mg} / \mathrm{l}$ were the most common values, which would correspond to mineralization of organic matter and leaching from corrals during wet periods (Aranibar et al., 2012; Meglioli et al., 2013). Nitrite contents were lower than nitrate concentrations in all samples analyzed, with values between $0.008 \mathrm{mg} / \mathrm{l}$ and $0.060 \mathrm{mg} / \mathrm{l}$.

Groundwater arsenic $\left(\mathrm{As}_{(\text {Total }}\right)$ concentrations ranged from 9 to $500 \mu \mathrm{g} / \mathrm{l}$ and showed significant spatial variation (Fig.6). There is no clear association between the concentration of arsenic and other chemicals. There is no relationship between $\mathrm{As}_{\text {(Total) }}$ and $\mathrm{pH}$, electrical conductivity, depth, or bicarbonates contents. Mineralogical studies and lithological descriptions by CRAS (1978) indicate the presence of volcanic glass in sediments as a probable source of groundwater $\mathrm{As}_{(\text {Total) }}$. Variability in $\mathrm{As}_{\text {(Total) }}$ contents (Fig.6) is coincident with volcanic ash heterogeneity distributions. Arid and semi-arid climates can contribute to the genesis of As-rich groundwater, due

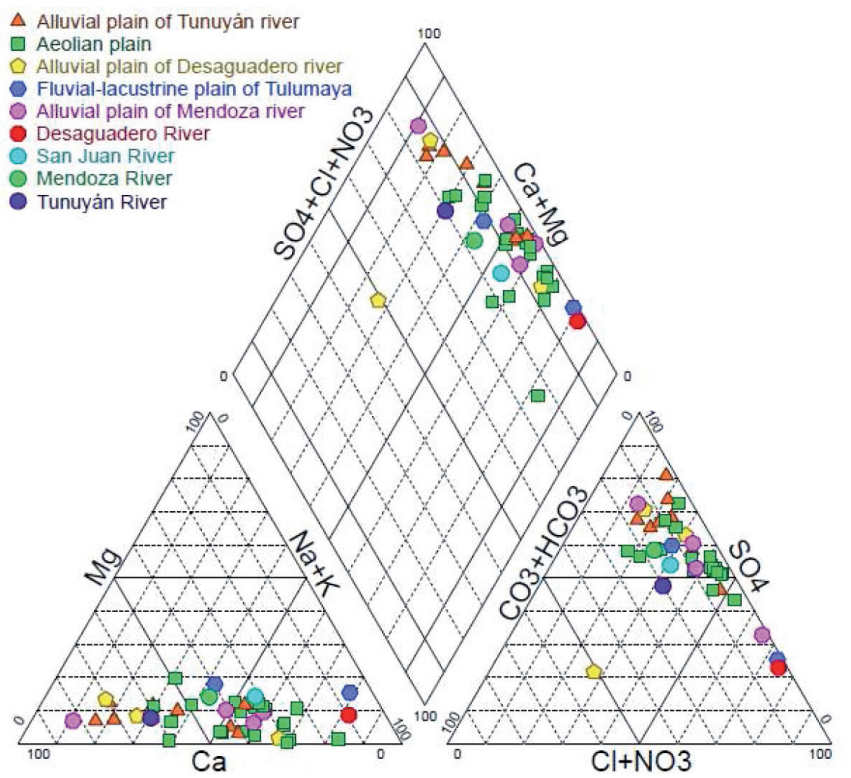

Fig. 5.- Piper diagram showing the groundwater and surface water taken from each geomorphological unit.

to evaporative increase of $\mathrm{As}_{\text {(Total) }}$ concentration in water, as suggested by Nicolli et al. (2010).

Arsenic mostly occurs as $\mathrm{As}(\mathrm{V})$, although As (III) is also present in several samples, with up to $40 \%$ of the total $\mathrm{As}_{\text {(Total) }}$ in 4 samples (Table 1). Inorganic arsenic compounds are about 100 times more toxic than organic arsenic compounds (Jain and Ali, 2000), and the toxicity of As(III) is higher than that of As(V) (Berman, 1980; Gesamp, 1986). As(III) is present in deep, thermal waters, and in shallow groundwater that might have organic inputs from livestock corrals (Meglioli et al.,
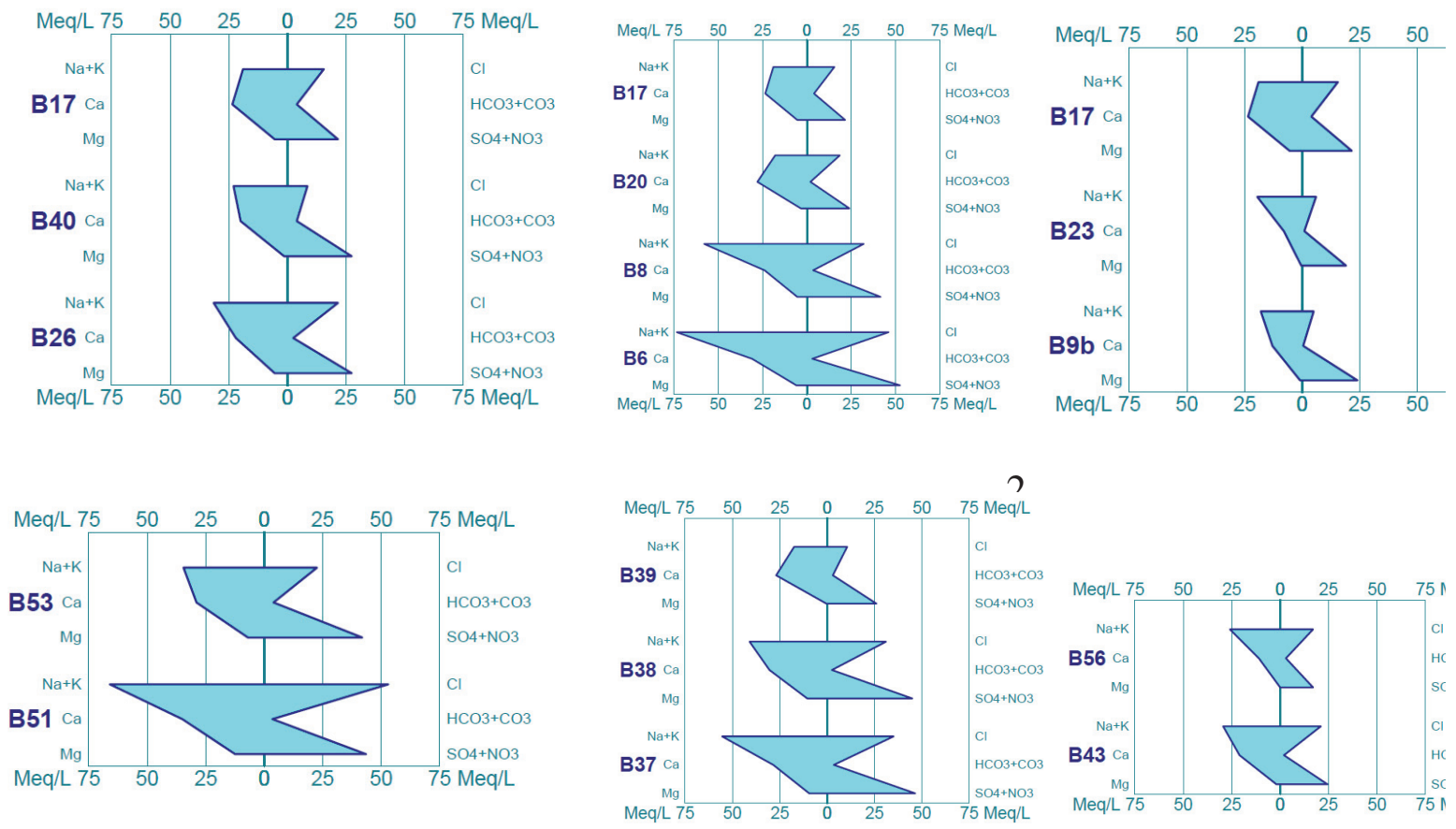

Fig. 6.- Groundwater geochemical evolution along local flow lines. Well locations are indicated in Figure 1. 


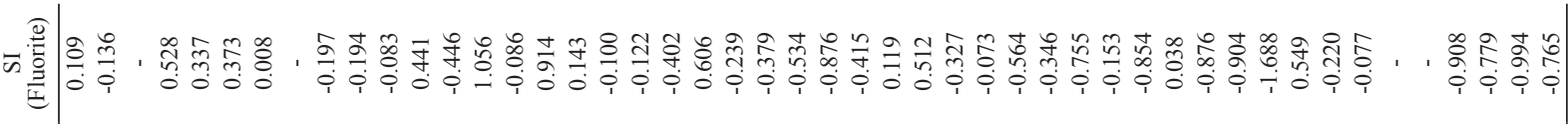

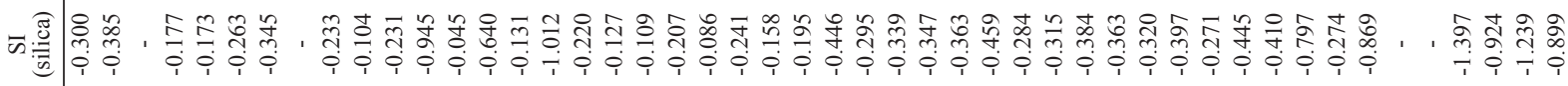

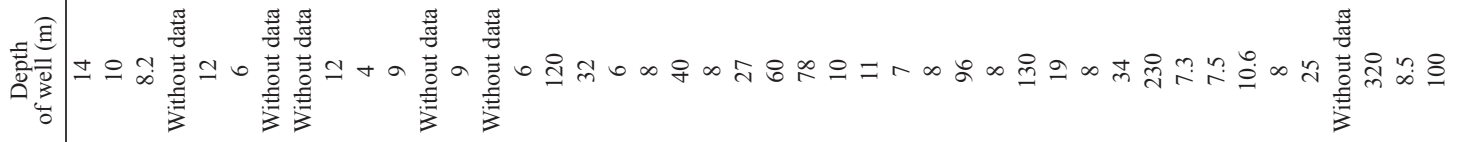

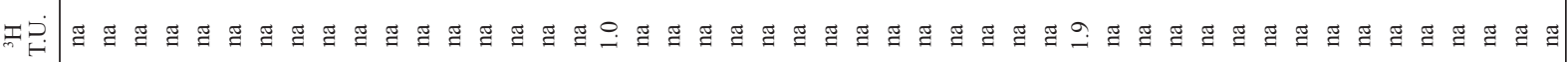

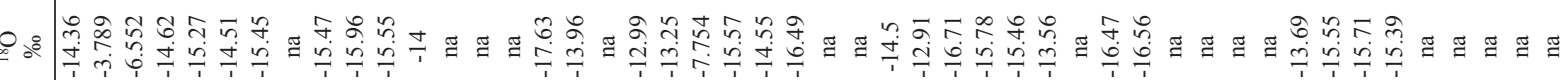

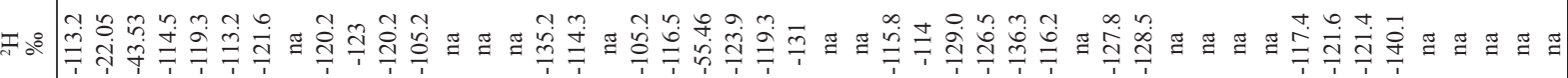

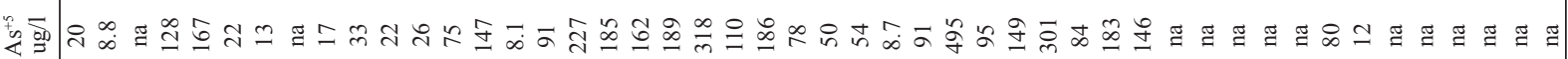

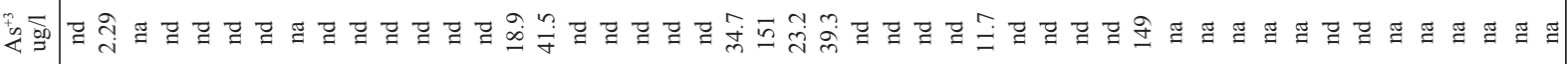

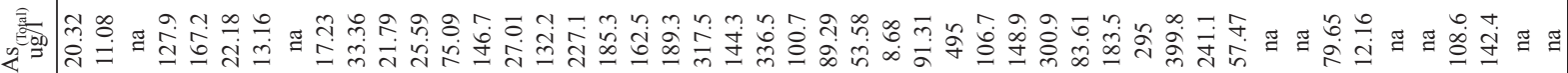

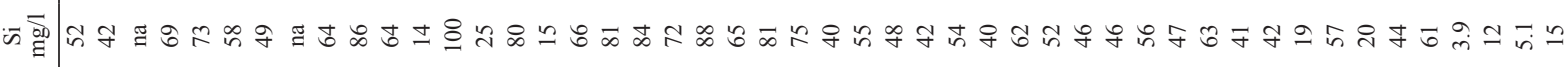

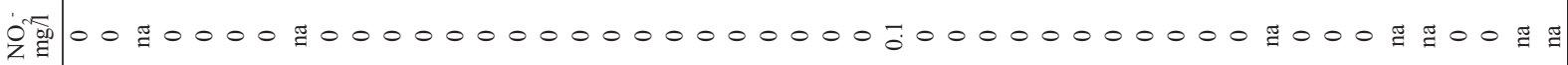

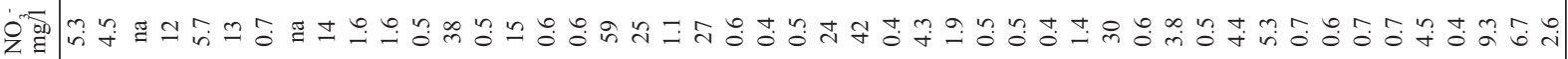

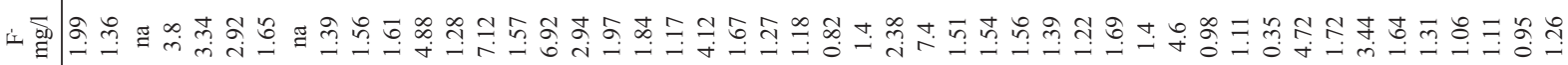

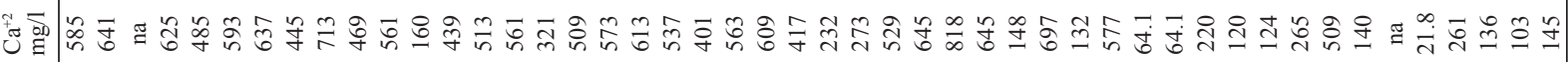

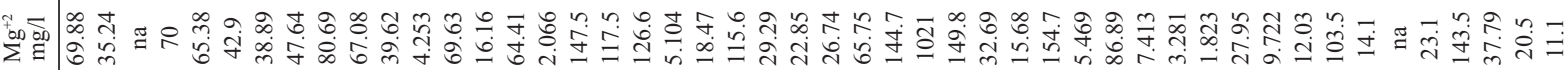

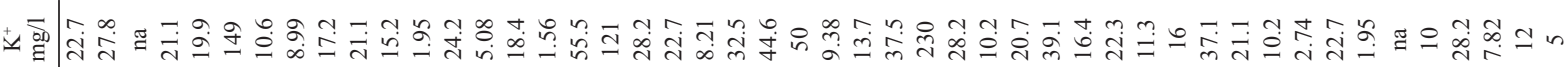

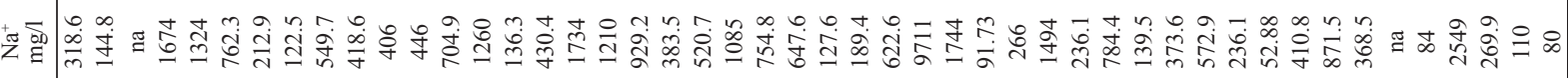

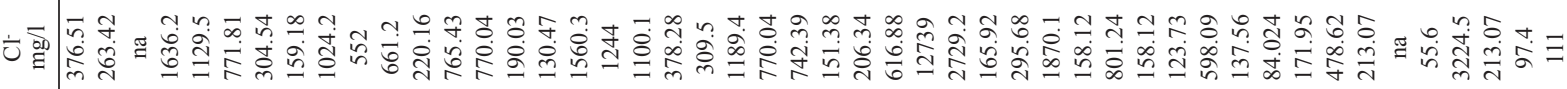

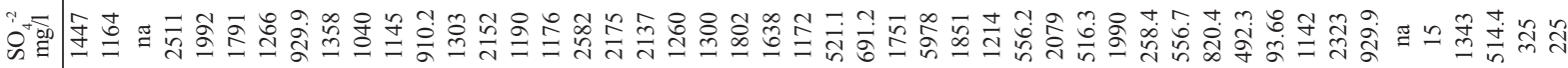

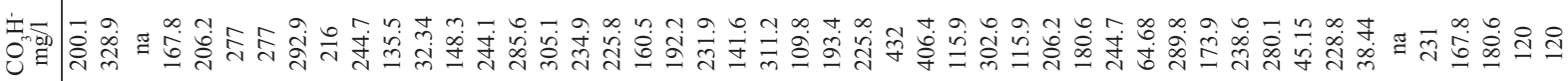

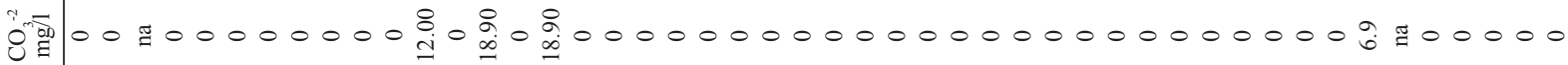

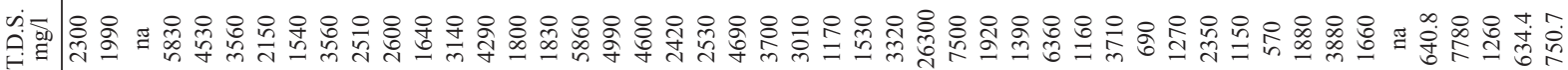

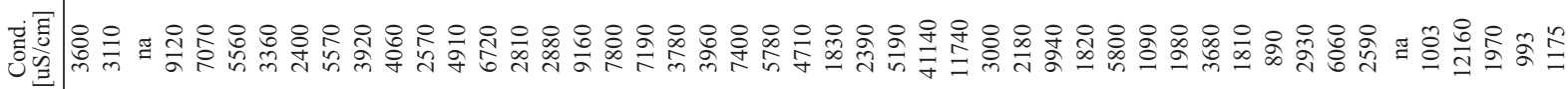

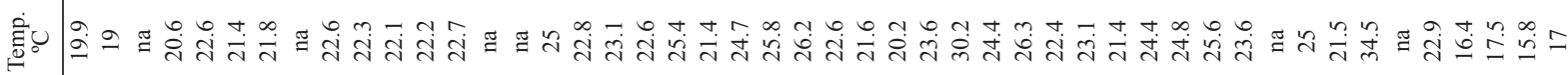
I

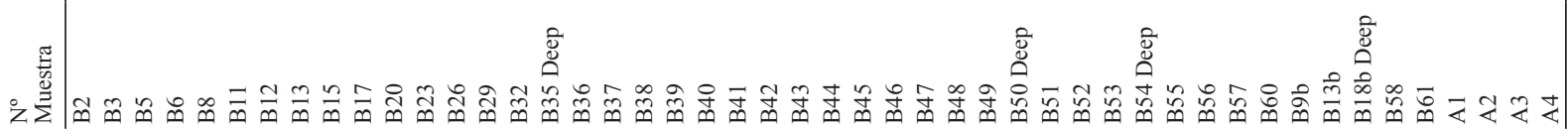



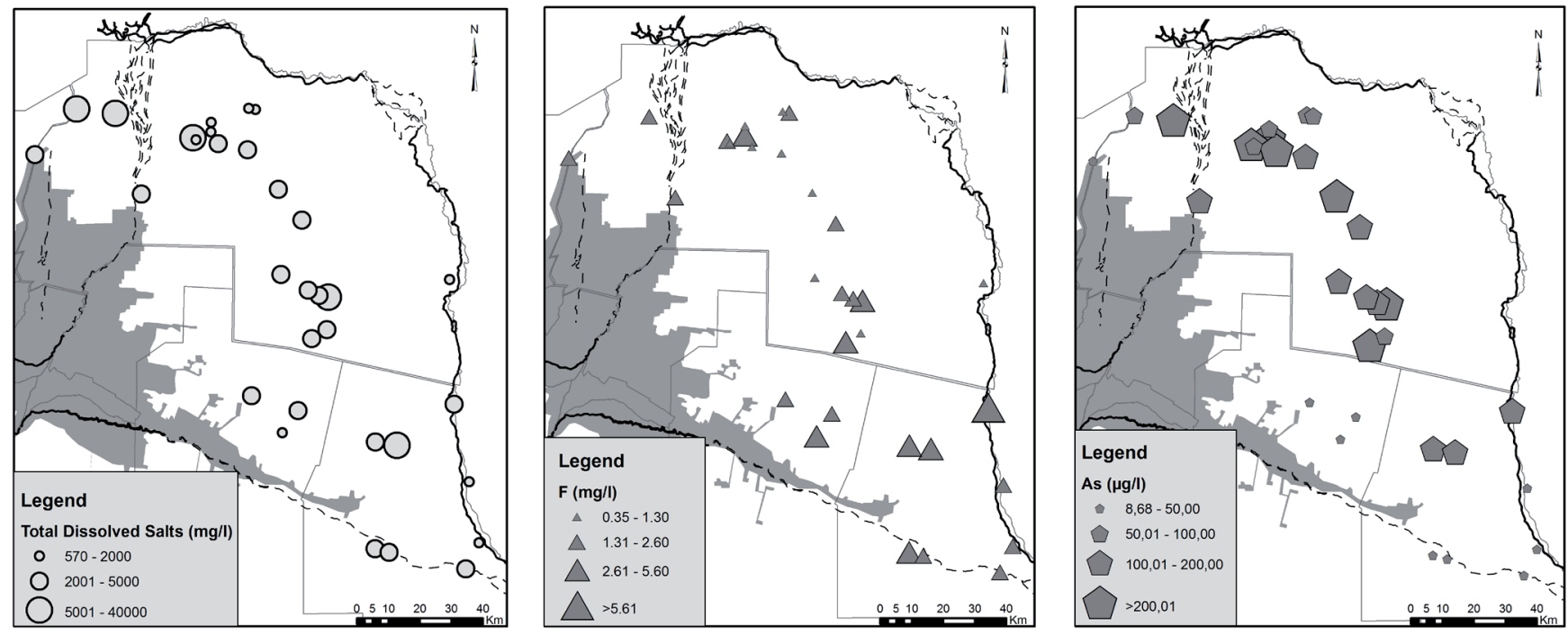

Fig. 7.- Distribution of TDS, $\mathrm{As}_{\text {(Total) }}$ and $\mathrm{F}^{-}$in groundwater in northeast Mendoza.

2013). The weak, but significant correlation between As and water temperature supports the hypothesis of deep groundwater circulation stated in the hydrological model.

The distribution of $\mathrm{F}^{-}$in groundwater is heterogeneous, similar to the $\mathrm{As}_{\text {(Total) }}$ distribution (Fig.7). Fluoride concentrations vary between $0.35 \mathrm{mg} / \mathrm{l}$ and $7.40 \mathrm{mg} / \mathrm{l}$. Although numerous studies indicate the presence and association of $\mathrm{As}_{\text {(Total) }}$ and $\mathrm{F}$ in aquifers in the Pampas region of Argentina (Smedley et al., 2002; Bhattacharya et al., 2006; Gomez et al., 2009), this correlation was not found in the aquifer of northeast Mendoza $(\mathrm{R}=0.07)$. There are no associations between $\mathrm{As}_{\text {(Total) }}$ and $\mathrm{F}^{-}$with $\mathrm{Ca}^{+2}$ and $\mathrm{Mg}^{+2}$ concentrations $(\mathrm{R}<0.32)$. For $\mathrm{F}^{-}$concentrations below $2 \mathrm{mg} / \mathrm{l}$, there is appear a weak positive association between $\mathrm{F}^{-}, \mathrm{Si}, \mathrm{Na}^{+}$, and $\mathrm{Mg}^{+2}(\mathrm{R}=0.48$ in all cases). Acidic sediments from the Andes (mainly rhyolitic compositions) may be the source of $\mathrm{As}_{\text {(Total) }}$ and $\mathrm{F}^{-}$in groundwater (Smedley et al., 2002). Particularly high concentrations of $\mathrm{Na}^{+}, \mathrm{Ca}^{+2}$ and $\mathrm{SO}_{4}^{-2}$ would reduce the concentration of both trace elements in solution, associated with the high mirabilite and gypsum dissolution (Cordini, 1948). Many authors have reported the low affinity between As and $\mathrm{F}^{-}$with calcium in groundwater (Bundshchuh et al. 2000; Smedley et al.2002; Valenzuela and Ramírez 2004; Gomez et al., 2009; and others). High concentrations of $\mathrm{Ca}^{+2}$ in groundwater may generate sufficient availability for its precipitation with $\mathrm{F}^{-}$. Saturation indices indicate that some samples could be supersaturated with fluorite, in waters with highest $\mathrm{F}^{-}$concentrations (Table 1).

The precipitation of $\mathrm{F}^{-}$as $\mathrm{CaF}_{2}$ (a compound of low solubility) may determine lower F-concentrations than expected in this aquifer, which has volcanic sediments. The process of gypsum dissolution and $\mathrm{CaCO}_{3}$ (a common mineral in the aquifer) allows $\mathrm{Ca}^{+2}$ concentration to continue to increase. This gypsum may originate from gypsum deposits in the central Andes (Ramos, 1996), in the recharge area of the aquifer, and other mineral compositions such as silica compounds (i.e., hornblende). Turner et al. (2005) have shown that in addition to $\mathrm{CaF}_{2}$ precipitation, surface calcite adsorption may control $\mathrm{F}^{-}$in solution. In this study, $\mathrm{CaCO}_{3}$ was found in the aquifer and unsaturated zone and we considered the hypothesis of that process

\subsection{Hydrogeological Conceptual Model}

The geological-geomorphological and hydrochemical characteristics of high salinity, the presence of As(III) and thermalism in groundwater are consistent with an interpretation of a hydrological regime of a discharge area in NE of Mendoza, with vertical ascendant flows (Fig. 9). The influence of these flows, controlled by elevated surrounding areas, and local flows, constrained by geological structures, paleochannels and sand dunes (Fig. 9), determine water quality in the region. It is concluded that the geological setting of faults in the area has been the key factor in the development of groundwater flow. The hydrochemical characteristics are controlled by mineralogical and hidrogeochemical possesses, mainly dissolution of gypsum, silicates and volcanic glass, combined with arid conditions. The lack of precipitation and abundant phreatophytic vegetation (Meglioli et al., 2013) prevents and delays $\mathrm{NO}_{3}^{-}$inputs into the aquifer, explaining the generally low concentrations of nitrate found in most of the area. Nitrate leaching near livestock settlements, where vegetation has been removed, may be accompanied by organic inputs, which may generate reducing conditions that favor arsenic reduction to As(III).

\subsection{Geochemical mass-balance modeling}

Microscopy studies indicated the dominance of amphiboles, plagioclase, k-rich spar, quartz and, in lower propor- 


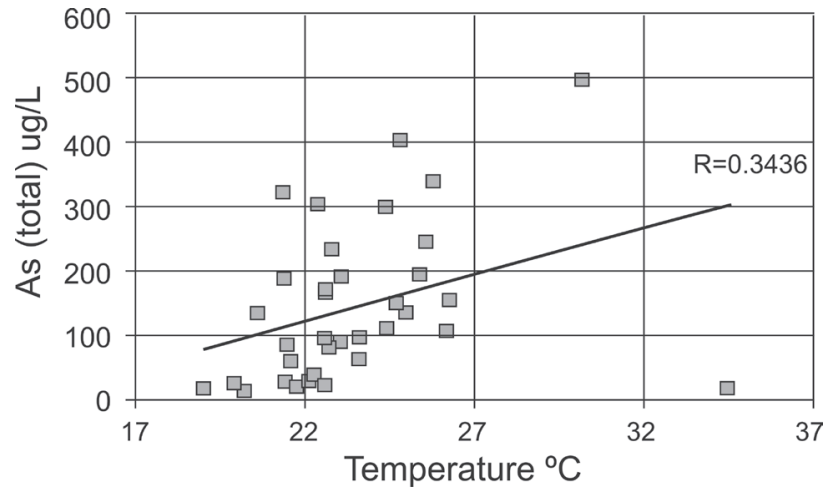

Fig. 8.- Correlation between As(Total) and temperature in groundwaters from northeast Mendoza

tions (below 5\%), volcanic ash, apatite, opaque minerals and muscovite. In loupe analyses, all samples reacted with hydrochloric acid, indicating an abundance of dispersed carbonates. Silicate minerals were subangular and very altered in many cases, with sericite on their surface. Volcanic ash was not altered, without sharp-edgesor inclusions. X-ray diffraction analyses show the presence of quartz, K-rich feldspar, plagioclase, amphibole, gypsum, calcite, cristobalite and clay minerals, with probable dominance of illite. These analyses are similar to other mineralogical studies in northeast Mendoza (Cordini, 1948; Carpio,1999), which include salt flats as well as sulfate and chloride salt deposits (gypsum, mirabilite, halite). According to well descriptions and geological history (Sepúlveda, 2001) this mineralogy may be representative of the fine sand layer, up to $270 \mathrm{~m}$ deep.

In order to fit the hydrogeological conceptual model NETPATH code (Plummer et al. 1991) was used to perform inverse modeling under different scenarios. The overall high salinity and homogeneous hydrochemical phases in groundwater do not show a normal evolution (Chevotarev, 1955) in flow direction, so it's believed that the conceptual model of the discharge area reflects short stretches of geochemical evolution following the same overall flow line. It tries to explain the compositions between groundwater samples along the same flow line over short distances.

Main ions $\left(\mathrm{HCO}_{3}^{-}, \mathrm{SO}_{4}^{-2}, \mathrm{Cl}^{-}, \mathrm{Na}^{+}, \mathrm{K}^{+}, \mathrm{Ca}^{+2}, \mathrm{Mg}^{+2}\right), \mathrm{F}^{-}$and $\mathrm{Si}$ were considered in all models. Phases indicated in the mineralogical analysis and background data were included. Fluorapatite phases were considered because of their influences on the contribution and mobility of $\mathrm{F}^{-}$. The modeling calculates equilibrium speciation of groundwater and selects reactions that are thermodynamically correct. Results are indicated in Table 2.

The mineral saturation index (SI) for calcite ranges between 2.14 and 0.077 , indicating supersaturation or near saturation conditions. High supersaturation values, not compatible with the thermodynamic theory, can be explained by differential kinetics between gypsum dissolution with $\mathrm{Ca}^{+2}$ and calcite precipitation. Gypsum SI ranges between -1.47 and -0.014 , indicating that groundwater is subsaturated with respect to this evaporite mineral. Silica (amorphous) SI ranges between
-1.37 and -0.13 , which indicates subsaturated conditions with respect to volcanic ash.

The geochemical models show that cation exchange defines cation concentration in groundwater. High concentrations of calcium and sodium from gypsum and $\mathrm{NaSO}_{4}$ dissolutions promote cation exchange with the clay mineral in the aquifer, mainly illite. The exchange phase indicates that a fraction of $\mathrm{Na}^{+}$is exchanged for $\mathrm{Ca}^{+2}$ and $\mathrm{Mg}^{+2}$ in most cases. Calcite indicates precipitation in most of the models and some cases of dissolution according to the SI, and also the abundance of carbonates, probably of calcium, in all analyzed samples. Silicate (Hornblende/K spar/amphibole) dissolution is also responsible for groundwater composition. The negative sign and low values in the illite phase indicate precipitation or near equilibrium conditions that may show neoformation of clay, present in low proportion in sediments.

For models 5, 11, 13 and 15, which had water in the paleochannels, a high dissolution and precipitation of $\mathrm{NaCl}$ and other phases were needed to explain water composition, which is not likely to occur in the study area. In those cases, mixing problems with surface water from the Mendoza and Tunuyán rivers were needed to explain groundwater composition (Table 2, Fig. 1 and 3). These mixing problems indicated the same hydrogeochemical process mentioned above (dissolution/precipitation/cation exchange), but with a significant input of surface river water. This evidence suggests that groundwater in this paleochannel was recharged locally by the Mendoza river when it followed this course (Fig. 3).

\subsection{Stable isotopes}

Stable isotope compositions $\left(\delta^{18} \mathrm{O}\right.$ and $\left.\delta^{2} \mathrm{H}\right)$ of groundwater show, in general, a low dispersion around surface water and precipitation values, based on studies by Crespo et al. (2012), Hoke et al.(2013), and Aranibar et al. (2011). They are isotopically heavier compared to waters from the Andes (Fig. 10). The most depleted samples in the Local Meteoric Water Line (LMWL) are from precipitation in the Andes (Hoke et al., 2013), as a consequence of the altitude effect, while the most enriched samples are from rain in the eastern lowlands (Aranibar et al., 2011) (Fig. 10).

Groundwater isotope composition can be divided in two main groups. The first one shows higher $\delta^{18} \mathrm{O}$ and $\delta^{2} \mathrm{H}$ values (B3, B5, B23, B40) and is plotted over the meteoric-water line (Fig. 10). Studies from Jobbágy et al.(2011) in northeast of Mendoza, indicate that, in some sites, groundwater did not match the isotopic signature of two temporary ponds sampled after a large rainfall event, evidencing the lack of local recharge. The isotopic compositions in B3, B5, B23, B40 samples indicate that they were affected by local precipitation, but at a very local scale..

The second group includes most of the samples. Groundwater taken from different depths (from 14 to $320 \mathrm{~m}$ ) shows isotopically depleted compositions $\left(\delta^{18} \mathrm{O}:-17.58 \%\right.$ to -12.99 $\%$ and $\delta^{2} \mathrm{H}:-140.13 \%$ o to $-105.15 \%$ o) compared to the first 


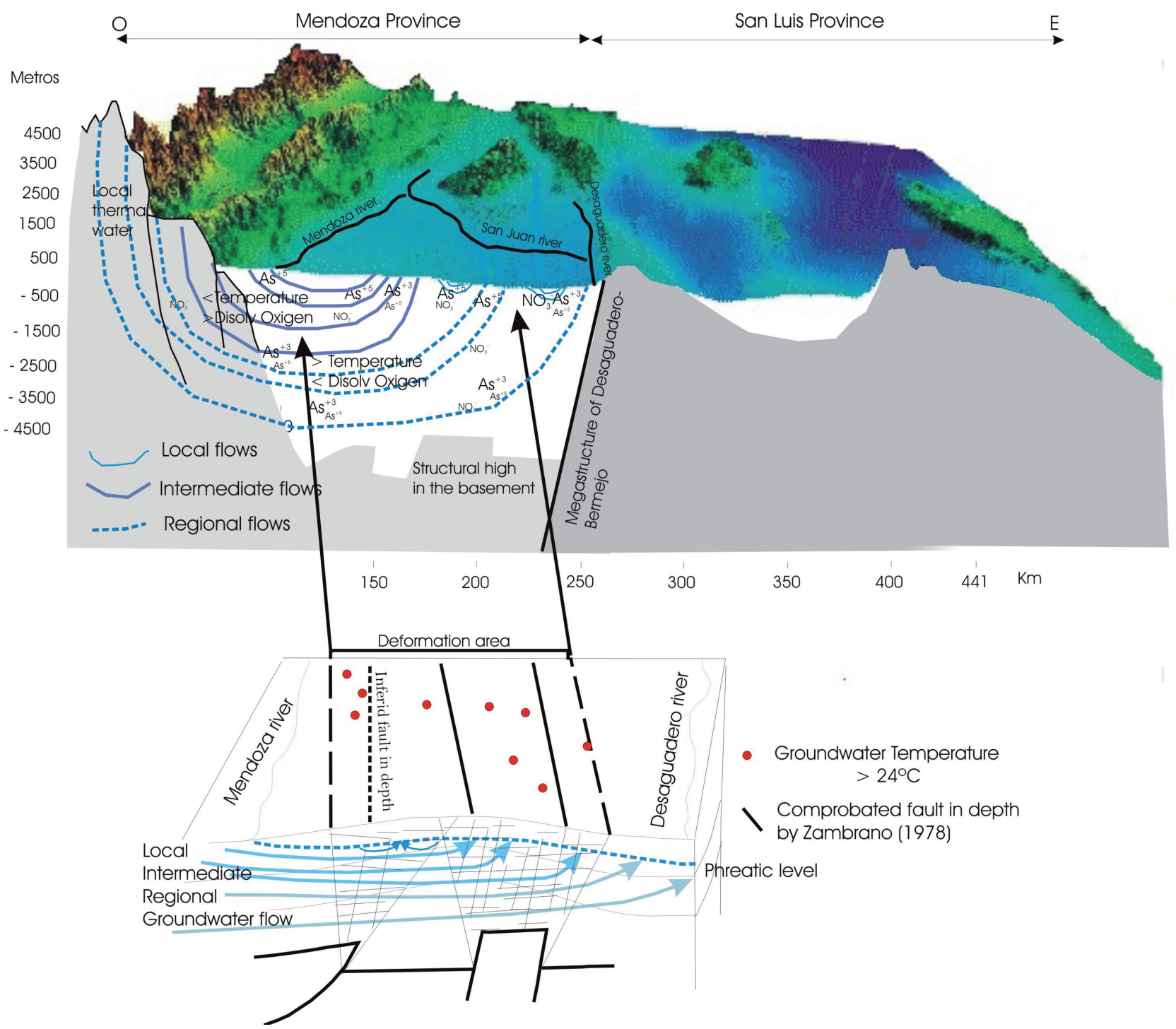

Fig. 9- Conceptual hydrogeological model in northeast Mendoza. Groundwater flows are shown with blue lines.

Fig. 10.- Groundwater stable isotopes.

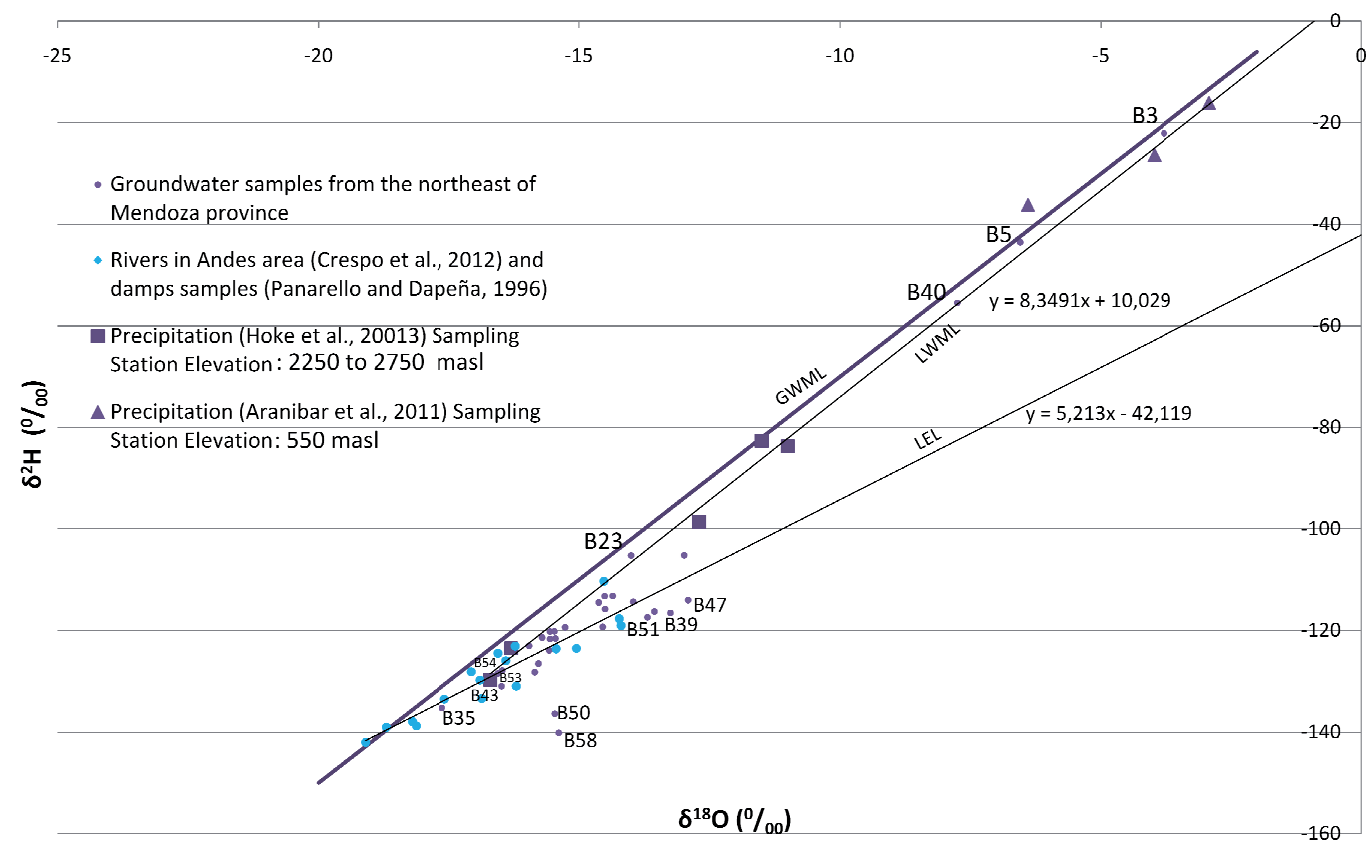


group. Some depleted groundwater samples are plotted near the LMWL, indicating a similar composition to Andean rivers (Fig. 9). Other samples fall between this line and the LEL (Local Evaporation Line: $\delta^{2} \mathrm{H}=5.21 * \delta^{18} \mathrm{O}-42.12$ ), which is defined by the composition of waters from dams (Panarello and Dapeña, 1996), originating in surface water from Andean rivers (Crespo et al., 2012). This distribution indicates remote recharge from northeastern Mendoza by infiltration in river beds downstream of the dams. Geological studies and profile analysis indicated the presence, at the east, of extensive areas occupied by lakes in areas near of Mendoza River, from which the evaporation of water prior to infiltration and subsequent recharge to the aquifer may have occurred. The age of groundwater near Mendoza river, increases from west to east, in a range from greater than 50 years to more than 13,000 years (Vogel et al., 1975).

The deep samples B35, B43, B53, B54 and B18b (Fig. 10) are plotted near LWML and have lower values in $\delta^{18} \mathrm{O}$ and $\delta^{2} \mathrm{H}$ than some surface waters in the Andes (Fig. 10). According to the conceptual model (Fig. 9) and the age obtained by Vogel et al. (1975) the hypothesis for deep groundwater suggests the influence of old regional groundwater flows recharged in different climate conditions or that they correspond to a faster groundwater flow due to structural framework and lithological conditions. It is necessary to include ${ }^{3} \mathrm{H}, \delta^{13} \mathrm{C}$ and $\delta^{14} \mathrm{C}$ analysis to ensure its age.

It is hypothesized that the oldest groundwaters are those whose temperature is $4^{\circ}$ above annual average, because of vertical upward flow. The relationship between temperature and depth shows a good correlation $(\mathrm{R}=0.79)$, taking into account the fact that it has few deep samples. Low isotope values in deep samples may be indicative of other groundwater recharge conditions, such as lower temperature and moisture in the past (Figs. 11a and 11b). Markgraf (1989) reports that late-Pleistocene climates prior to 12,000 years BP were cold- er everywhere in South America, and substantially windier at high latitudes. Figure 11 shows the lowest stable isotope values $\left(\delta^{18} \mathrm{O}\right.$ and $\left.\delta^{2} \mathrm{H}\right)$ among deep groundwater samples, supporting the conceptual model of vertical upward flow and its recharge in different climate conditions (Fig. 9). The B58 and B50 isotopic compositions have $\delta^{18} \mathrm{O}$ heavier than LEL and would require meteoric starting waters too light to explain it, suggesting an analytical laboratory error.

The conceptual model of vertical ascendant groundwater may explain the tritium values in groundwater of northeastern Mendoza. Due to nuclear bomb testing, atmospheric tritium levels began to increase in Argentina in 1954 from a background concentration of between 4 TU (Gat, 1980) and 8 TU (in 1997) to a maximum of 54.2 TU in 1966, decreasing after toward current levels (Logan and Rudolph, 1997). Jobbágy and Jackson (2007) identified a threshold of $<1 \mathrm{TU}$ for water recharged prior to 1960 , a range of 1 to 3.5 TU for water recharged between 1960 and 1963, and a threshold of $>3.5$ TU for water inputs from 1963 to the present. Panarello and Dapeña (1996) measured tritium in rain water and the Mendoza River to be $9 \mathrm{TU}$ and 6.2 TU, respectively. In this studies, tritium analyses (B52: 1.9 TU) may indicate mixing between shallow (younger) and deeper (older) groundwater. Values of groundwater tritium in the upper part of the aquifer and in a sand area (B37: $1.0 \mathrm{TU}$ ) suggest the absence of recent recharge from rain, where it was expected a higher local recharge. This supports the hypothesis of a system mainly disconnected from the current hydrometeorogical cycle. Jobbágy et al. (2011) studied the relationship between rainfall and piezometric levels and confirm this disconnection. Their measurements show recharge rates of $<1 \mathrm{~mm} /$ year in vegetated uplands and no recharge in vegetated lowlands, also show a watertable fluctuations less than $10 \mathrm{~mm}$ after an important rain

Processes

\begin{tabular}{|c|c|c|c|c|c|c|c|c|c|c|c|c|c|}
\hline \multirow[b]{2}{*}{ Model } & \multirow[b]{2}{*}{$\begin{array}{c}\text { Well } \\
\text { (Initial Water) }\end{array}$} & \\
\hline & & $\begin{array}{c}\text { Well } \\
\text { (Final Water) }\end{array}$ & $\begin{array}{c}\text { Disol/Precip } \\
\text { of calcite }\end{array}$ & $\mathrm{CO}_{2} \mathrm{Gas}$ & $\begin{array}{l}\text { Exchange } \\
\mathrm{Ca}^{+2} / \mathrm{Na}^{+}\end{array}$ & $\begin{array}{c}\mathrm{Mg}^{+2} / \mathrm{Na}^{+} \\
\text {Ex. }\end{array}$ & $\begin{array}{l}\text { Disol of } \\
\text { K-Spar }\end{array}$ & Hornblende & Illite & Fluorapatite & $\mathrm{Na}_{2} \mathrm{SO}_{4}$ & $\mathrm{NaCl}$ & Gypsum \\
\hline 1 & $\mathrm{~B} 20$ & B8 & 3.27297 & -- & 14.50905 & -1.06894 & 0.12148 & - & - & 0.09174 & - & - & - \\
\hline 2 & B17 & B23 & -4.54126 & 0.81284 & - & 2.59203 & $\begin{array}{l}0.49148 \\
0.00455\end{array}$ & - & - & 0.17498 & $\begin{array}{l}2.69111 \\
1.08962\end{array}$ & - & - \\
\hline 3 & $\mathrm{~B} 17$ & $\mathrm{~B} 20$ & -1.97940 & - & -4.12627 & 1.21633 & - & 0.14827 & -0.25800 & 0.00265 & - & 3.09151 & - \\
\hline 4 & B17 & B26 & -1.92948 & - & - & 0.49614 & 1.62514 & 1.24676 & -2.57408 & -0.01473 & 2.73051 & 6.05372 & 0.02152 \\
\hline 5 & $\mathrm{~B} 17$ & $\mathrm{~B} 40$ & -1.43729 & 1.13193 & 2.00525 & - & -0.33087 & - & - & 0.13514 & 3.65120 & -6.86005 & -0.94359 \\
\hline 6 & $\mathrm{~B} 17+\mathrm{A} 4$ & B40 & & & & & & & & & & & \\
\hline & $45 \%+55 \%$ & & - & 0.94533 & - & 0.81304 & - & 0.12067 & -0.17271 & 0.14392 & 5.47502 & - & 1.91382 \\
\hline 7 & B52 & B45 & -3.12435 & 2.53431 & 0.64760 & -1.42327 & 0.02233 & 2.38309 & -0.03314 & - & - & - & - \\
\hline 8 & B57 & B45 & -1.89223 & 1.42051 & -1.98715 & - & - & 1.63719 & -0.31687 & - & - & 1.94501 & 2.07564 \\
\hline 9 & B57 & B44 & -1.02921 & - & -3.00782 & 0.44936 & - & 0.52468 & -0.50063 & - & - & 0.39029 & 0.30026 \\
\hline 10 & B56 & B43 & 1.81146 & -2.97385 & 0.57473 & -0.98326 & 0.60890 & - & -0.46158 & - & - & 4.09612 & 3.68329 \\
\hline 11 & B53 & B57 & -14.95509 & 15.15960 & -2.58704 & - & 5.82195 & - & -9.75672 & - & - & -18.8184 & -15.67817 \\
\hline 12 & $\begin{array}{l}\mathrm{B} 53+\mathrm{A} 3 \\
6 \%+94 \%\end{array}$ & B57 & 0.72727 & 1.26274 & 1.15428 & - & 0.21834 & 0.15095 & - & 0.00622 & 0.75417 & - & - \\
\hline 13 & $\mathrm{~B} 53+\mathrm{A} 3$ & B52 & & & & & & & & & & & \\
\hline & $9 \%+91 \%$ & & -1.46709 & 2.22967 & - & 1.47935 & 0.09050 & 0.62453 & - & 0.01088 & - & - & 0.49736 \\
\hline 14 & B53 & B55 & -1.40814 & 2.26556 & - & 3.38768 & - & - & -0.27017 & 0.15312 & -2.78462 & -19.2084 & -12.22173 \\
\hline 15 & $\begin{array}{l}\mathrm{B} 53+\mathrm{A} 3 \\
4 \%+96 \%\end{array}$ & B55 & - & 2.67993 & 4.25786 & 0.93386 & 0.09351 & 0.12246 & - & 0.19097 & - & & 1.76658 \\
\hline 16 & B52 & B44 & 0.14314 & - & -1.81349 & -0.45456 & - & 0.49659 & -0.30045 & - & - & -0.1902 & 0.05011 \\
\hline
\end{tabular}

Table 2.- Hydrogeochemical models in groundwater in northeast Mendoza. Values are in moles/l. 


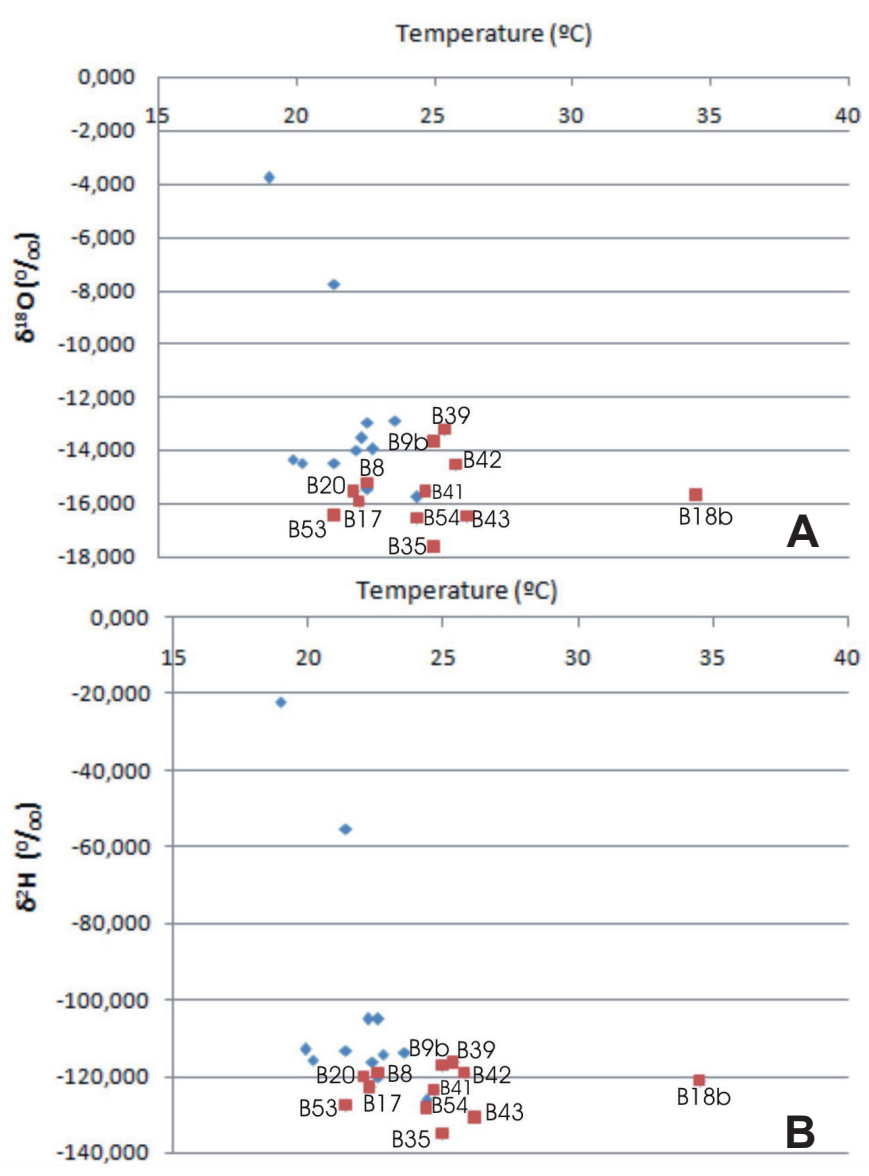

Fig. 11.- Groundwater stable isotopes plotted against groundwater temperature. A) $\delta^{18} \mathrm{O}$; B) $\delta^{2} \mathrm{H}$. The squares represent deeper groundwater samples and those with temperatures $>25^{\circ} \mathrm{C}$, including 3 shallow groundwater samples.

event of $51 \mathrm{~mm}$, suggesting that the recent recharge from rain is a negligible process.

\section{Conclusions}

A conceptual model of the hydrogeological system in northeast Mendoza has been presented. The model is a simplification of the reality, based on an extensive review of previous research and other scattered information related to the geomorphological, geological and structural framework. In this work new hydrodynamic and hydrogeochemical data, including groundwater temperature and isotopic analyses were provided.

The region is delimited by the Mendoza, San Juan, Tunuyán and Desaguadero rivers, and is one of the most arid areas of South America. The plains are part of a large depression filled with fluvial and aeolian sediments (Sepúlveda, 2001; Rodriguez, 1963). The Cenozoic structural control associated with the Andes uplift determines a sedimentary basin framework (Sepúlveda, 2001) and defines current surface and groundwater flows. Zambrano (1978) and Martínez et al. (2008) showed evidence of a structure in the basement controlling the flow of northeastern rivers in the past. The existence of new structures, according to the unpublished structured map by Zambrano (1978) was proposed in the area. Associated seismological data confirm the present lifting of structures, but topographic and hydrodynamic analyses suggest that this occurs at very low velocities. Above these structures, sedimentary rocks could include an area of deformations (with faults and folds), allowing deep groundwater flows to rise to shallower levels.

The natural occurrence of high total dissolved salts, hardness, $\mathrm{As}_{(\text {Total })}$ and F-content is related to the mineralogical and textural characteristics of the aquifer sediments and high groundwater residence times in a regional area of alluvial fans at the foothill of Andes range. Low groundwater salinity in northern paleochannels and tritium data indicate recharge from the Mendoza river in the past, when the river flowed in paleochannels (ancient recharge). Historic documents and archeological remains suggest the historic presence of rivers in the paleochannel (Prieto and Abraham, 2000; Chiavazza and Prieto, 2008; Chiavazza, 2013). However, as a local and unusual phenomenon, the possibility of a very local groundwater recharge process from rainwater retention ponds, as was observed in a well near Arroyito village is not ruled out.

A geomorphological discharge area, structural framework, low recharge rates, remote recharge, dominance of fine sediments, and salt deposits result in a particular hydrogeological setting and low variability of groundwater salt content. This is reflected in relatively uniform hydrochemical composition (sodium-calcium sulfate groundwater) in samples taken throughout the area. Nitrate and nitrite in groundwater are frequently present in low concentrations, due to low precipitations and low groundwater recharge from rainfall. Rainfall, in humid areas, causes surface nitrogen from corrals to percolate into the aquifer, increasing groundwater nitrate contents (Gomez et al., 2009).

The hydrological model indicates a discharge area in rivers and lakes, as seen in wetlands, marshes, lagoons, salt deposits and high salinity in surface water and groundwater. Groundwater discharge may also occur through the phreatophyte vegetation (Prosopis flexuosa woodlands), estimated by Jobbágy et al. (2011) to be $296 \mathrm{~mm} /$ year.

Estimated values of groundwater flow velocity reflect the fine sediments and flat relief, but it is probable that the values vary with scale, due to the influence of lower permeability levels at different depths (see profiles in Fig. 2). The geological setting of alluvial fan and the structural framework generate a complex groundwater flow in the area.

Isotopic analyses of groundwaters show a dominant recharge by surface water from the Andes, as suggested by studies in the irrigated oasis and northwest of the study area, by Vogel et al. (1975), Panarello and Dapeña (1996), Aranibar et al (2011) and Jobbágy et al. (2011). The low isotopic values in deep groundwater samples may be indicative of other groundwater recharge conditions which present different isotopic values from rain and surface water. The main problem in this assumption is the availability of access to 
deep groundwater. The informal economy and reduced possibilities of finding better quality groundwater make it difficult to access deep groundwater.

Associated with the hydrogeological model of the discharge area, vertical upward groundwater flows are demonstrated by thermal waters and the presence of As(III) in some samples, which can be associated with more reducing conditions in the deep aquifer and can also be developed in wetlands close to river bed.

Based on these different lines of evidence, the better quality (i.e., lower salinity) groundwaters found in the paleochannels may not be considered renewable, because the river has permanently changed its course. The hydrographic framework suggests tectonic activity lifted part of the area, moving rivers and drying wetlands. Geophysical studies are needed to define the structural structure of the basin, and in particular, to confirm the presence of inferred structures which can cause upwelling of thermal groundwaters and river migration.

The need for sanitary measures to ensure availability of drinking water for local communities is highlighted. Human activities have not significantly affected the aquifer, but local nitrate leaching and arsenic reduction in a few wells suggest that more intense livestock activities and water availability may change groundwater chemistry in the future, increasing nitrate and As(III) concentration.

\section{Acknowledgements}

The authors wish to acknowledge A. Alvarez, J. Bartolomeo, M Martinis of the National Water Institute (INA-CRA), C. Regairás, C. Vega, P. Meglioli, E. Barrio, E. Corvalán, M. Quiroga, F. Ríos, D. Araneo, A. Tripaldi and M. R. Prieto for providing materials, information, and help during field work. We also thank Nelly Oak for help with the English, and E. Jobbágy, M. Demartis, L. Giambiagi, J. Mescua, and C. Mugas for help with the review and discussions. We are grateful to T. Musso from Universidad Nacional del Comahue for collaborating with X-ray mineralogical analyses. This work was supported by the Ministry of Science and Technology, National Agency for Science and Technology (PICT 20091222 granted to P. Villagra; PICT-PRH 2011-2703 granted to J. Aranibar), and the Universidad Nacional de Cuyo (SECTyP projects PID 2009-2011 and 2011-2013 granted to J. Aranibar). The authors acknowledge the two anonymous referees and their detailed comments and revisions to improve the manuscript.

\section{References}

Abraham, E. M. (2000): Geomorfología de la Provincia de Mendoza. En Abraham, E. M. \& F. Rodríguez Martínez (eds) Argentina. Recursos y Problemas Ambientales de la Zona Árida I y II Caracterización Ambiental y Mapa básico 1: 29-47.

Abraham, E., Prieto, M. (1981): Enfoque diacrónico de los cambios ecológicos y de las adaptaciones humanas en el NE. árido mendocino. In: J. C. Ruiz (ed.), Cuaderno $N^{\circ} 8$, CEIFAR-CONICET-UNC,
Mendoza, 108-139

Abraham, E., Soria, D., Rubio, C., Fernández, R. (2008): Tercer Informe de Avance. Sitio Piloto Mendoza. Región Centro Oeste (52 p.). Proyecto Evaluación de la Degradación de Tierras en Zonas Áridas. FAO, PAN y Secretaría de Acción Nacional de Lucha contra la Desertificación. Laboratorio de Desertificación y Ordenamiento Territorial-IADIZA, CCT Mendoza.

Alvarez, J. A., Villagra, P., Cony, M., Cesca, E., Boninsegna, J. (2006): Estructura y estado de conservación de los bosques de Prosopis flexuosa D.C. en el Noreste de Mendoza, Argentina. Revista Chilena de Historia Natural 79, 75-87.

Alvarez, J. A., Villagra, P., Villalba, R., Cony, M. A., Alberto, M. (2011): Wood productivity of Prosopis flexuosa D.C. woodlands in the central Monte: Influence of population structure and tree-growth habit. Journal of Arid Environments 75, 7-13.

Alvarez, M. P., Weiler, N., Hernández, M. (2009): Geomorphology and hydrodynamics: a case study from Península Valdés, Patagonia, Argentina. Hydrogeology Journal 18(2), 473-486. Doi:10.1007/s10040009-0528-x.

APHA, AWWA, WPCF. (1995): Standard methods for the examination of water and wastewater, $17^{\text {th }}$ ed. Washington.

ASTM. (1993): Anual Book of Standards. Section 4, vol. 4.08 Soil and Rock.D.2488.

Aranibar, J., Villagra, P., Gomez, L., Jobbágy, E., Quiroga, M., Wuilloud, R., Monasterio, R., Guevara, A. (2011): Nitrate dynamics in the soil and unconfined aquifer in arid groundwater coupled ecosystems of the Monte desert, Argentina. Journal of Geophysical Research 116, g04015, doi:10.1029/2010jg001618.

Bradbury, K., Muldoon, M. (1990): Hydraulic conductivity determinations in unlithified glacial and fluvial materials. In: D.M. Nielsen, A.I. Johnson (eds.), Ground Water and Vadose Zone Monitoring. American Society for Testing and Materials STP 1053, pp. 138-151.

Bhattacharya, P., Claesson, M., Bundschuh, J., Sracek, O., Fagerberg, J., Jacks, G., Martin, R., Storniolo, A., Thir, J. (2006): Distribution and mobility of arsenic in the Río Dulce alluvial aquifers in Santiago del Estero Province, Argentina. Science of the Total Environment 358, 97- 120. doi: 10.1016/j.scitotenv.2005.04.048.

Berman, E. (1980): Toxic Metals and Their Analysis. Heyden and Sons, London. pp. 293.

Bordonaro, O. (2012): Mundos extinguidos de Mendoza. 1ra ed. Mendoza: Zeta Editores. pp142.

Bundschuh J., Bonorino G., Viero, A., Albouy, R., Fuertes, A. (2000): Arsenic and other trace elements in sedimentary aquifers in the Chaco-Pampean Plain, Argentina: $31^{\text {st }}$ International Geol. Cong., Rio de Janeiro, Brazil, 2000, pp 27-32.

Carpio, F. (1999): Sulfatera General San Martín, Mendoza. In: Recursos Minerales de la República Argentina (Ed. E. O. Zappettini), Instituto de Geología y Recursos Minerales SEGEMAR, Anales 35, $1943-$ 1946, Buenos Aires.

Chebotarev, I. (1955): Metamorphism of Natural Waters in the Crust of Weathering-1. Geochimica et Cosmochimica Acta 8, 22-48.

Chiavazza, H. (2013): Vivir y moverse en el desierto: la ocupación humana en entornos áridos (NE de Mendoza, Argentina). X Jornadas de Arqueología y Etnohistoria del COA. Tercer seminario Magistral "Las sociedades de los paisajes áridos y Semiáridos del COA". Córdoba. 2013.

Chiavazza, H., Prieto, M. (2008): Estudios arqueológicos en el Río Desaguadero. Runa 29, 29-51.

Cordini, R. (1948): Cuerpos salinos de la Argentina. Revista de la Asociación Geológica Argentina III (3), 145-199.

CRAS (1978): Centro Regional de Aguas Subterráneas. Investigación inicial del recurso hídrico subterráneo de la Zona Nororiental de la Provincia de Mendoza. Serie Técnica, P-222, Mendoza, pp. 60.

Crespo, S., Gomez, L., Aranibar, J., Schwikowski, M., Corvalán, J. 
(2012): Características químicas e isotópicas de glaciares, arroyos y vertientes de la cuenca alta del río Mendoza, Andes centrales de Argentina. II Reunión Argentina de Geoquímica de la Superficie. Bahía Blanca.

Custodio, E., Llamas, M. (1983): Hidrogeología subterránea. $2^{\text {nd }}$ Ed. Omega. Barcelona. pp. 1.500.

Domenico, P., Schwartz, W. (1990): Physical and chemical hydrogeology. John Wiley and Sons, pp. 824.

Edmunds, M. (2012): Limits to the availability of groundwater in Africa. Environmental Resource Lett. 7 .021003 . 3pp. doi:10.1088/17489326/7/2/021003.

Gesamp. L. (1986): Joint Group of Experts on the Scientific Aspects of Marine Pollution, Review of potentially harmful substances-arsenic, mercury and selenium, Rept. Stud, GESAMP 28.

Giantomasi, A., Roig-Junent, F., Villagra, P. (2013): Use of differential water sources by Prosopis flexuosa DC: a dendroecological study. Plant Ecology 214, 11-27. doi: 10.1007/s11258-012-0141-2 Pp. 214:11-27.

Goirán, S., Aranibar, J., Gomez, L. (2012): Heterogeneous spatial distribution of traditional livestock settlements and their effects on vegetation cover in arid groundwater coupled ecosystems in the Monte desert (Argentina). Journal of Arid Environments 87, 188-197. doi: 10.1016/j.jaridenv.2012.07.011

Gomez, L., Blarasin, M., Martínez, D. (2009): Arsenic and fluoride in a loess aquifer in the central area of Argentine. Environmental Geology 57,143-155. doi: 10.1007/s00254-008-1290-4.

Gonfiantini, R. (1978): Standards for stable isotope measurements in natural compounds. Nature, 271. pp. 534.

Hu, S., Luo, T., Jing, Ch. (2012): Principal component analysis of fluoride geochemistry of groundwater in Shanxi and Inner Mongolia, China. Journal of Geochemical Exploration. doi: 10.1016/j.gexplo.2012.08.013.

Hoke, G., Aranibar, J., Viale, M., Araneo, D., Llano, C. (2013): Seasonal moisture sources and the isotopic composition of precipitation, rivers, and carbonates across the Andes at $32.5-35.5^{\circ} \mathrm{S}$. Geochemistry, Geophysics, Geosystems 14 (4), 962-978.

Jain, C., Ali, I. (2000): Arsenic: occurrence, toxicity and speciation techniques. Water Resource 34 (17), 4304-4312. doi: 10.1016/S00431354(00)00182-2.

Jobbágy, E., Nosetto, M., Villagra, P., Jackson, R. (2011): Water subsidies from mountains to deserts: Their role sustaining groundwater-fed oases in a sandy landscape. Ecological Applications 21(3), 678-694. doi: 10.1890/09-1427.1.

Jobbágy, E., Jackson, R. (2007): Groundwater and soil chemical changes under phreatophytic tree plantations. Journal of geophysical research 112, G02013, doi: 10.1029/2006JG000246.

INPRES. (2013): National Institute of Seismic Prevention. http://www. inpres.gov.ar/seismology/xultimos.php

Kalnay, E., Co-authors. (1996): The NCEP/NCAR Reanalysis 40-year Project. Bull. Amer. Meteor. Soc. 77, 437-471. doi: 10.1175/1520-0477(1996)077<0437:TNYRP >2.0.CO;2.

Keller, C., Van der Kamp, G., Cherry, J. (1989): A multiscale study of the permeability of thick clayey till. Water Resource Research 25, 2299-2317. doi: 10.1029/WR025i011p02299.

Last, W., Smol, S. (2000): Tacking environmental change using lake sediments. 2, Phisical and geochemical methods. Kluwer academic publishers. Dordrecht. The Netherlands. doi: 10.1007/0-306-4767034.

Logan, W., Rudolph, D. (1997): Micro depression-focused recharge in a coastal wetland, La Plata, Argentina. Journal of Hydrology 194, 221-238. doi: 10.1029/2003WR002982.

Markgraf, V. (1989): Paleoclimates in Central and South America since 18,000 BP based on pollen and lake-level records. Quaternary Science Reviews 8, 1-24. doi: 10.1016/0277-3791(89)90018-8
Martínez, P., Perucca, L., Giménez, M., Ruíz, F. (2008): Manifestaciones geomorfológicas y geofísicas de una estructura geológica profunda al sur de la sierra de Pie de Palo, Sierras Pampeanas. Revista de la Asociación Geológica Argentina 63 (2), 264 - 271.

Meglioli, P., Aranibar, J., Villagra, P., Alvarez, J., Jobbágy, E. (2013): Livestock stations as foci of groundwater recharge and nitrate leaching in a sandy desert of the Central Monte, Argentina. Ecohydrology 7 (2), 600-611. doi: 10.1002/eco.1381.

Neuzil, C. (1986): Groundwater flow in low-permeability environments. Water Resource Research 22, 1163-1195.

Nicolli, H., Bundschuh, J., García, W., Falcón, C., Jean, J. (2010): Sources and controls for the mobility of arsenic in oxidizing groundwaters from loess-type sediments in arid/semi-arid dry climates e Evidence from the ChacoePampean plain (Argentina). Water research 44, 5589 - 5604. doi:10.1016/j.watres.2010.09.029.

Panarello, H., Dapeña, C. (1996): Mecanismos de recarga y salinización en las cuencas de los ríos Mendoza y Tunuyán, Mendoza, República Argentina: evidenciados por isótopos ambientales. Memorias del XII Congreso Geológico de Bolivia II, 531-543. Sociedad Geológica Boliviana, Tarija, Bolivia.

Plummer, L., Prestemon, E., Parkhurst, D. (1991): An Interactive Code (NETPATH) for Modelling NET Geochemical Reactions along a Flow PATH. U.S.G.S. Water Resources Investigations 4078, 227 p.

Prieto, M., Abraham, E. (2000): Caminos y comercio como factores de cambio ambiental en las planicies áridas de Mendoza (Argentina) entre los siglos XVII y XIX. Revista Estudios sobre Sociedad, Naturaleza y Desarrollo. THEOMAI Journal 2 (second semester).

Prieto, R., Chiavazza, H. (2005): Aportes de la historia ambiental y la arqueología para el análisis del patrón de asentamiento Huarpe en el oasis norte de Mendoza. Anales de Arqueología y Etnología, Fac. de Filosofía y Letras., UNCuyo 59-60,163-195.

Ramos, V. (1996): Geología de la Región del Aconcagua. Provincias de San Juan y Mendoza. Anales $N^{\circ} 24$. Subsecretaría de minería de la nación. Dirección Nacional del Servicio Geológico, 114-116.

Ramsar (1999): Convención Relativa a los Humedales de Importancia Internacional especialmente como Hábitat de Aves Acuática. http:// www2.medioambiente.gov.ar/recursos_acuaticos/ramsar/guanacache.htm

Rodríguez, E. (1966): Estudio hidrogeológico del sector nordeste de la provincia de Mendoza. Rev. de la Asociación Geológica Argentina XXI (1), 39-60.

Sepúlveda, E. (2001): Hoja Geológica 3369-II. Mendoza, provincias de Mendoza. Y San Juan. Servicio Programa de Cartas Geológicas de la República Argentina. Esc. 1:250.000. Servicio Geológico Minero Argentino (SEGEMAR).

Smedley, P., Nicolli, H., Macdonald, D., Barros, A., Tullio, J. (2002): Hydrogeochemistry of arsenic and other inorganic constituents in groundwaters from La Pampa, Argentina. Applied Geochemistry 17, 259-284. doi: 10.1016/S0883-2927(01)00082-8

Struckmeier, W., Margat, J. (1995): Hydrological Maps. A Guide and a Standard Legend. International Contributions to Hydrogeology 17, $177 \mathrm{p}$.

Toth, J. (1999): Groundwater as a geologic agent: An overview of the causes, processes and manifestations. Hydrogeology Journal 7, 1-14.

Turner, B., Binnig, P., Stipp, L. (2005): Fluoride removal by calcite: Evidence for fluorite precipitation and surface adsorption. Environmental Science and Technology 39 (7), 9561-9568. doi: 10.1021/es0505090

Valenzuela Vásquez, L., Ramírez Hernández, J. (2004): Análisis del comportamiento del Flúor en el acuífero que abastece a Hermosillo, Sonora, México. XXXIII Congress IAH \& $7^{\circ}$ Congress ALHSUD. Zacatecas, México. ISBN: 970-32-1749-4.

Vogel, J., Lerman, J., Mook, W. (1975): Natural Isotopes in surface and groundwater from Argentina. Hydrological Sciences-Bulletin des Sciences Hydrologiques XX, 2-6. 
Williams, W. (1999): Salinisation: A major threat to water resources in the arid and semi-arid regions of the world. Lakes \& Reservoirs: Research \& Management 4, 85-91. doi: 10.1046/j.14401770.1999.00089.x

Zambrano, J. (1978): Mapa geotectónico del centro Oeste argentino, escala 1:1000000. Centro Regional de Aguas Subterráneas de San Juan (unpublished).

Zambrano, J. (1985): Regionalización hidrogeológica preliminar de la provincia de Mendoza. Centro Regional de Agua Subterránea, $12^{\circ}$ Congreso Nacional del Agua, Actas, Mendoza. Mapa estructural del valle de Tulum: su aplicación en la investigación del agua subterránea. Centro Regional de Agua Subterránea.

Zhang, O., Rodríguez-Lado, L., Johnson, A., Xue, H., Shi, J., Zheng, Q., Sun, G. (2012): Predicting the risk of arsenic contaminated groundwater in Shanxi Province, Northern China. Environmental Pollution 165, 118-123. doi: 10.1016/j.envpol.2012.02.020. 